\title{
CERÁMICA ÁTICA DEL POBLADO IBÉRICO DE LA LOMA DEL ESCORIAL (LOS NIETOS, CARTAGENA)
}

\author{
POR \\ CARLOS GARCÍA CANO \\ Centro Regional de Arqueología de Murcia \\ JOSÉ MIGUEL GARCÍA CANO \\ Museo de Murcia
}

\section{RESUMEN}

Este trabajo da a conocer un importante lote de cráteras de campana áticas de la primera mitad del siglo IV a. C., halladas en una misma habitación del poblado ibérico de La Loma del Escorial, lo que pone de manifiesto la importancia de este enclave como centro redistribuidor de cerámica de lujo entre las poblaciones indígenas del sureste español.

\section{SUMMARY}

This paper describes an important group of Attic pottery eight bell craters from the first half of the 4 th century BC, discovered together in a room in the Iberian settlement of La Loma del Escorial on the coast of Murcia. The pottery demonstrates the importance of this enclave as a centre for redistributing sumptuous pottery among the indigenous populations of the south-east of the Iberian peninsula.

I Queremos agradecer al Dr. D. Ricardo Olmos la amabilidad que ha tenido con nosotros al ofrecernos las páginas de AEspA para publicar la primera noticia de este importante hallazgo arqueológico. También queremos mostrarle nuestro agradecimiento más sincero por la ayuda prestada en la identificación del motivo iconográfico de la crátera núm. 1. 


\section{INTRODUCCIÓN}

El poblado ibérico de Los Nietos, conocido con el nombre de «La Loma del Escorial», está situado en la orilla meridional del Mar Menor, parcialmente sepultado por las edificaciones de esta localidad cartagenera. Se encuentra en el margen izquierdo de la desembocadura de la rambla Carrasquilla, también conocido como Legua de la Vaca.

El poblado se asienta sobre una llanura junto a la playa, pero la acumulación de los depósitos arqueológicos ha dado como resultado la formación de una colina artificial, un auténtico «tell», con unos cinco metros de altitud máxima sobre el nivel del mar.

Este yacimiento es conocido desde finales de los años cincuenta, cuando un campesino que estaba realizando labores agrícolas halló restos de cerámica que entregó al director del Museo Arqueológico de Cartagena, P. San Martín Moro. Este visitaría varias veces el poblado y su entorno.

Por fin en 1962 obtuvo permiso par realizar una campaña de excavación en el mes de septiembre (San Martín, P., 1964, 157-161). En dicha campaña se realizó un sondeo de $10 \times 9,5 \mathrm{~m}$. documentándose dos niveles constructivos y una importante cantidad de materiales cerámicos, que despertaron el interés de miembros del Instituto Arqueológico Alemán que dio como resultado el primer estudio científico de los materiales (Diehl, E., Schubart, H. y San Martín, P. 1964, 45-83).

En este estudio se puso de manifiesto la presencia de materiales áticos desde la primera mitad del siglo V a. C.; Kylix de rojo coral, pintor del grupo Bolonia 417, hasta finales del siglo IV a. C., tanto de figuras rojas como de barniz negro. Estos materiales han vuelto a ser publicados por Trías G., 1967, 383-387, y García Cano, J. M. 1982.

Desde 1962 no se han realizado excavaciones en este poblado hasta la actuación de la que ha sido objeto nuestro estudio, dirigida por uno de los firmantes. Dicha actuación estuvo condicionada por la puesta en vigor del plan de ordenamiento urbano de Los Nietos que sin ninguna sensibilidad en materia arqueológica prevé la casi total urbanización de La Loma del Escorial.

Así pues, nuestra excavación se realizó con carácter de urgencia durante los meses de febrero y marzo de 1990, y posteriormente en junio de 1990, en un solar sito en la calle norte de la urbanización «Villas Elena», que linda al este con la calle Salmonete y al oeste con la calle Torrecilla (Ver figura 1).

También es conocida la necrópolis de este conjunto ibérico, desde hace varios lustros. Está emplazada en una pequeña loma a unos $600 \mathrm{~m}$. al oeste del poblado. Ha sido excavada regularmente desde mediados de los años setenta hasta la primera mitad de los ochenta (Cruz Pérez, L., 1987, 183-255).

$\mathrm{Al}$ igual que el poblado se ha visto afectada por las nuevas urbanizaciones veraniegas, lo que motivó la realización de excavaciones de urgencia desde diciembre de 1988 y a lo largo de 1989 , dirigidas por C. García Cano, que dio como resultado la exhumación de 160 enterramientos con varios encachados tumulares de piedra, fechable entre la segunda mitad del siglo $\mathrm{V}$ a. C. y los primeros decenios del siglo II a. de C. 


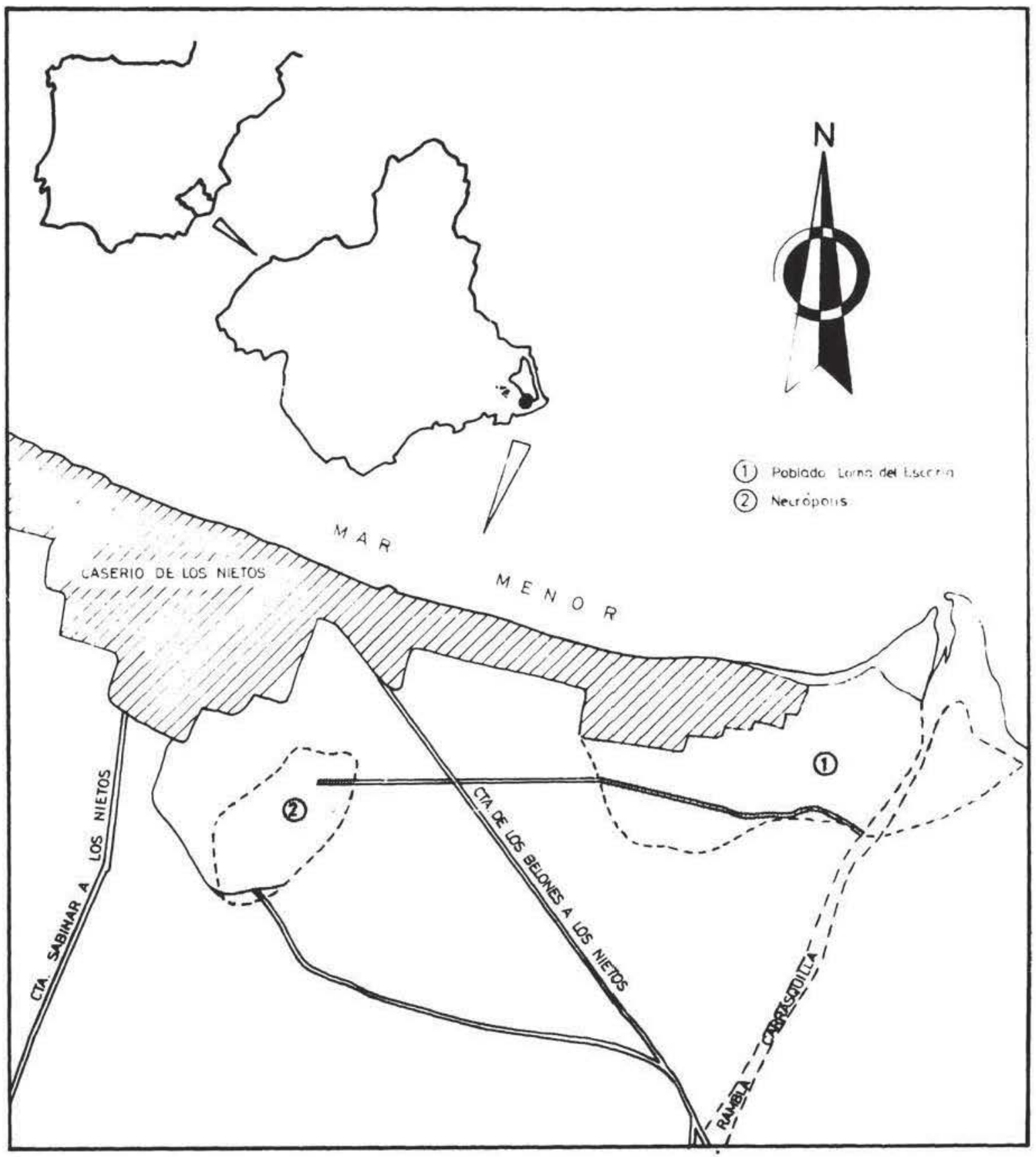

Figura 1.- Plano de ubicación del yacimiento ibérico de Los Nietos en la costa de Murcia.

\section{LA EXCAVACIÓN DE 1990}

Los trabajos arqueológicos han puesto de manifiesto la existencia de tres niveles de habitación. El más antiguo fechable en el siglo $\mathrm{V}$ a. C., apenas ha podido ser explorado, pero se documentaron muros perpendiculares con zócalos de piedra (nivel III). 
Hacia finales de este siglo o principios del siglo IV se produce una importante remodelación del poblado, en la cual es desmantelada la fase antigua, para levantar construcciones con una nueva disposición (nivel II).

Este nivel se mantuvo hasta mediados del siglo IV en el que se produjo su destrucción; la última fase constructiva se inicia a finales del siglo IV a. C. y perdura hasta los primeros decenios del siglo II a. C. en el que se abandona definitivamente.

El conjunto de cráteras áticas de figuras rojas cuyo estudio es el principal objeto de este trabajo, fue hallado en el interior de la habitación A del nivel II, del cual conocemos también la habitación B y la planta general en una extensión de $192 \mathrm{~m}^{2}$ (figura 2).

La habitación A se ubica en el centro aproximado del área excavada; tiene forma casi cuadrada de $4,60 \times 4 \mathrm{~m}$. La puerta se abre en el muro sur junto a la esquina suroeste, de 90 $\mathrm{cm}$. de anchura. Los muros están formados por un alto zócalo de piedra trabada con barro, de $85,4 \mathrm{~cm}$. de alzado y $40 \mathrm{~cm}$. de anchura. Conservaba una hilada de adobes que constituiría el resto del alzado. El depósito arqueológico documentado en el interior de la habitación A, corresponde al derrumbe de la misma. El estrato superior está formado por una potente disolución de adobes que incluye abundantes adobes completos o casi completos caídos en talud hacia el interior de la habitación. Debajo de esta espesa capa diferenciamos otro estrato con adobes con impronta de troncos, piñas y hojas de palmito, además de abundantes carbones y tierra con textura más suelta que interpretamos como correspondiente a la caída del techo.

Finalmente una fina capa de ceniza color negro de $4 \mathrm{~cm}$. de espesor que se extendía por encima de casi todo el pavimento, de color blanco. Fue localizado a la cota de $2,15 \mathrm{~m}$. sobre el nivel del mar.

Las cráteras números $1,2,3,4,5$ y 7 , fueron halladas junto al muro sur de la habitación, entremezcladas entre sí y con un ánfora púnica del área del Estrecho y otra ibérica, así como una fuente de mármol blanco.

Pensamos que estas seis cráteras estaban depositadas en una estantería situada a media altura del muro. Al desplomarse éste, las cráteras resbalarían por la repisa hacia la puerta, quedando los fragmentos entre los restos del muro caído, en pendiente desde la parte superior del zócalo de piedra hasta el pavimento en una extensión aproximada de dos metros cuadrados.

Las cráteras 6 y 8 aparecieron en el ángulo noroeste de la habitación junto a una ánfora de Chios que estaba incrustrada en el muro oeste, y otras tres ánforas ibéricas. Completaban el ajuar 4 grandes vasos de cerámica ibérica pintada.

Además fueron localizadas varias ánforas ibéricas, otros grandes vasos de almacenamiento, soportes de anillo, una botellita pintada con círculos concéntricos, una paterita F. 24 L., dos platos F. 21 y 22 . L. de cerámica ática de barniz negro datables en la primera mitad del siglo IV.

\section{CATÁLOGO Y ESTUDIO ICONOGRÁFICO}

Las cráteras sẹ han ordenado según el motivo iconográfico, respetándose el número de inventario de la excavación. 


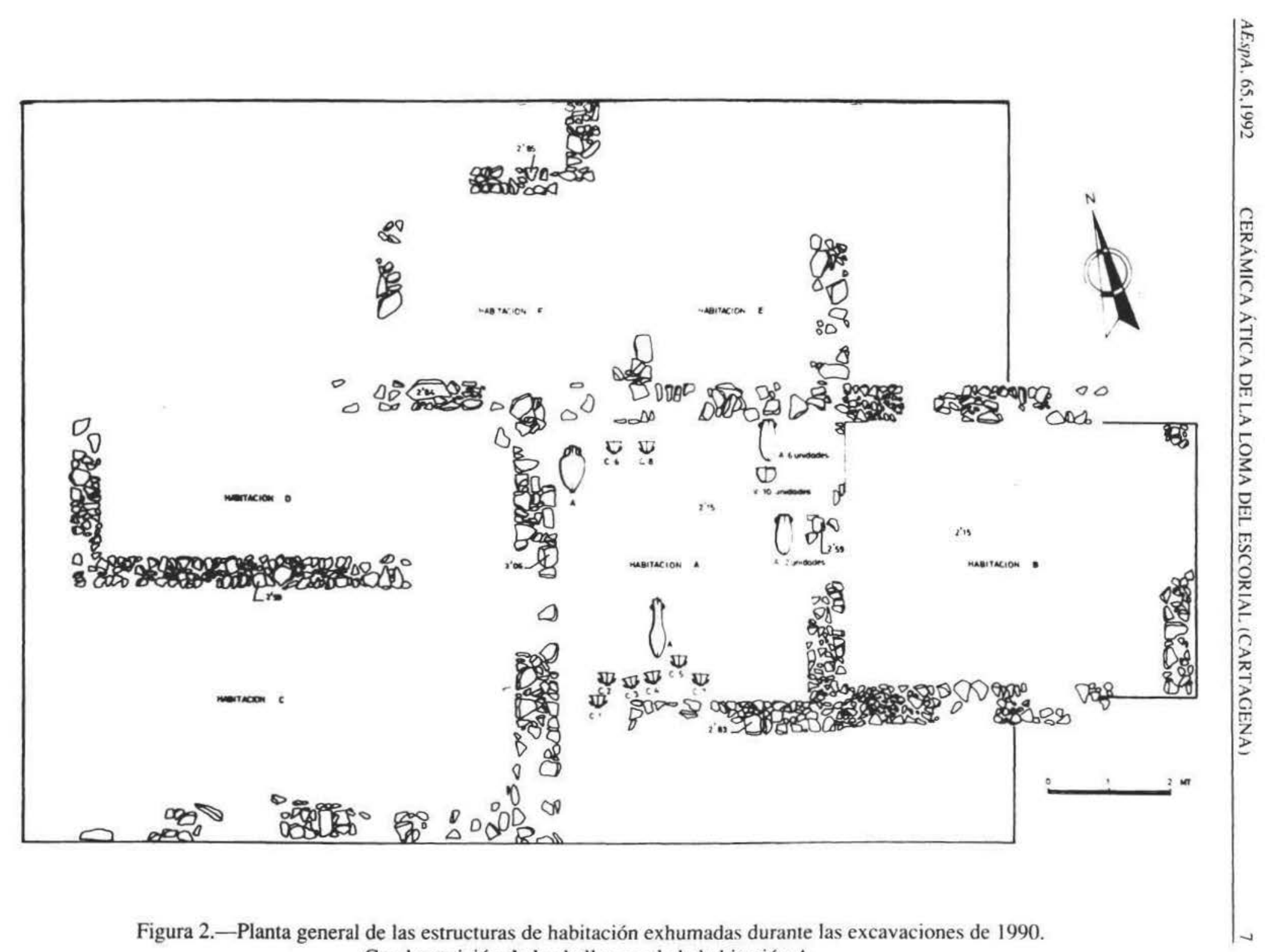
Con la posición de los hallazgos de la habitación A 


\section{FESTIVAL DE AP()L()}

Número 1. Cratera ática de campana de figuras rojas. Reconstruida y restaurada. Está muy fragmentada. pero practicamentre completa, en 86 fragmentos. Le falta una parte del borde y del asa izquierda. Dimensiones: $\mathrm{h}=395 \mathrm{~m} .: \mathrm{hp}=50 \mathrm{~mm} . ; \mathrm{db}=420 \mathrm{~mm} . ; \mathrm{dp}=199 \mathrm{~mm}$. Segundo cuarto del siglo IV a. C.

Barniz negro brillante, con tono oliváceo y reflejo metálico, tonos rojizos tanto al interior como al exterior. Un poco picado en el exterior. Varios fragmentos están quemados. Pasta anaranjada, blanda. depurada, grano muy fino.

Exterior: en la boca hojas de laurel hacia la izquierda; en la unión del cuerpo con la boca una pequeña acanaladura en reserva. La escena se apoya sobre un friso con grecas y ajedrezados alternando en proporción tres a uno. Acanaladura en reserva en la unión del pie con la base, y otra línea reservada en la carena del pie. Fondo externo sin barnizar. Friso de ovas alrededor del arranque de las asas.

a) Procesión al templo de Apolo (figura 3). En el centro de la escena destaca un jinete, montado en un caballo sobrepintado en blanco, que se dirige hacia la derecha. El caballo muestra los ornamentos con barniz diluido que adquiere tonos dorados: crines, cola, ojo, arreos y riendas. La montura es una piel de leopardo extendida, con la cabeza apoyada en el costado derecho del ca-

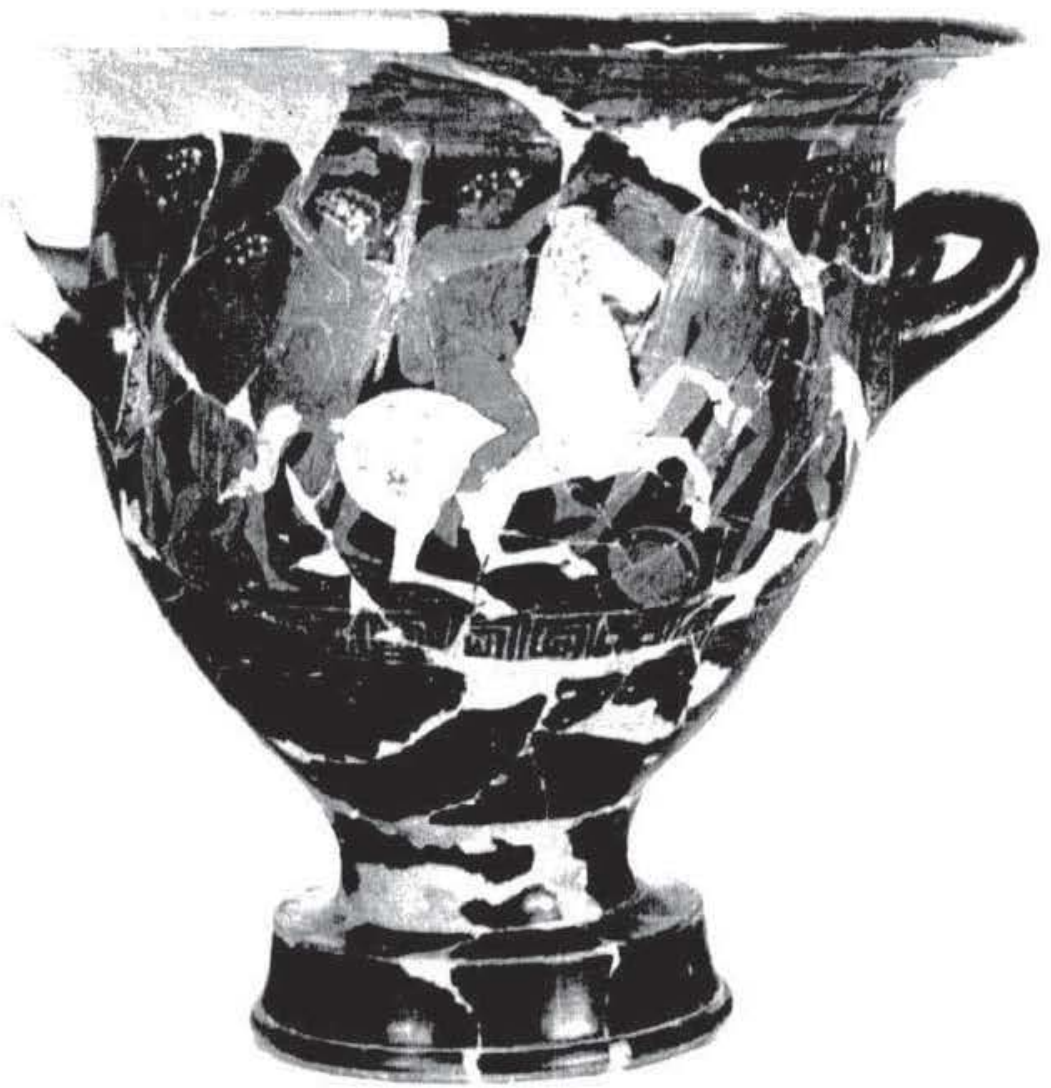

Figura 3.-Crátera núm. 1. Procesión al templo de Apolo Pitio. (Foto J. L. Montero). 
ballo, y la cola y los cuartos traseros en la parte posterior. Está realizada igualmente con barniz diluido sobre la pintura blanca. El jinete, desnudo, en tres cuartos, tiene el cabello rizado, con un rizo sobre la oreja y un tocado de hojas de laurel alternados con frutos blancos. Este peinado se repite en los seis personajes de la imagen. El brazo derecho extendido hacia adelante, dirigiendo la marcha de la procesión. Colgado del hombro izquierdo lleva la clámide con numerosos pliegues. Los rasgos anatómicos son muy sumarios: el pie izquierdo asoma por debajo del caballo desproporcionadamente largo.

Detrás del caballo, hacia la izquierda, otro joven desnudo, con la clámide colgada y el mismo peinado ya descrito. Se dirige hacia la derecha con la cabeza vuelta hacia atrás. La mano izquierda sustenta una antorcha, con la llama en pintura blanca sobre pintada. La derecha es levantada indicando la marcha. A su lado aparece un niño también desnudo, dirigiéndose hacia la derecha. Porta la misma indumentaria y peinado; apoyada en el hombro izquierdo lleva

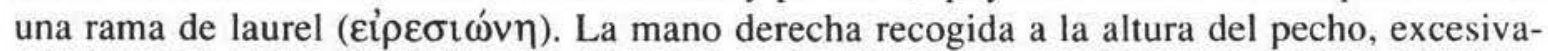
mente grande. Tras él otro joven desnudo completa la escena, alentando con su brazo derecho el sentido de la marcha, mientras con su brazo izquierdo sostiene una antorcha.

$\mathrm{Al}$ otro lado de la escena, delante del caballo, dos jóvenes, también desnudos, con el peinado e indumentaria ya referida. El primero lleva un paño blanco en el cuello, cayéndole los dos extremos del mismo sobre el pecho. Sujeta una antorcha con la mano izquierda y la derecha la dirige hacia el jinete. Entre sus pies se dispone un pandero parcialmente tapado por el caballo. Cierra la escena el segundo, que se dirige a la izquierda con una antorcha, mientras que levanta la mano derecha a la altura de la boca. Tras él, en el extremo de la escena, en la parte superior se observan una jamba y un dintel de la puerta del templo de Apolo, con detalles en pintura blanca. Del dintel cuelga una gran rama de laurel con frutos en blanco (figura 4).

b) Escena de palestra (figura 5). Tres jóvenes envueltos en grandes himátia dialogan. Dos se dirigen hacia la derecha, totalmente envueltos en sus mantos que sólo dejan asomar los pies. Los himátia están hechos mediante finas líneas de barniz diluido. Por lo que respecta a los rasgos anatómicos, apenas están esbozados; los cabellos son simples manchas de barniz, de los que cuelgan algunos rizos. Los ojos son líneas de barniz negro y la boca un punto. El tercer personaje se enfrenta a ellos, con un brazo extendido, y un disco en la mano izquierda. Segundo cuarto del siglo IV a. C.

Pensamos que el motivo iconográfico que exhibe esta crátera puede relacionarse con las fiestas que en honor de Apolo se celebraban en Atenas. Estas consistían en una procesión al santuario del dios, seguramente Pitio, donde se le presentaban una selección de los primeros frutos de la cosecha, dos veces al año, durante las Thargélia y Pyanópsia, correspondientes a los meses de mayo y octubre, con el fin de que el dios bendijera las cosechas (Deubner, L., 1969, 198).

Nuestra procesión corresponde a la que se celebraba en segundo lugar, esto es el siete de pyanopsion, en donde los oferentes llevaban los frutos del momento al santuario del dios, principalmente judías $(\pi v ́ \alpha v \alpha)$. Este día era costumbre que acompañara al cortejo un niño de padres vivos ( $\pi \alpha i \zeta \alpha \dot{\alpha} \mu \varphi(\theta \alpha \lambda \hat{\eta} \varsigma$ ) (figura 6) que llevaba en un hombro una rama de laurel, denominada eiresione (Simon, E., 1983, 76-77). Esta era colocada encima de la puerta del templo. Así mismo también era usual que otros ( $\pi \alpha \tilde{i} \delta \varepsilon \varsigma \alpha \mu \varphi 1 \theta \alpha \lambda \varepsilon i ̃ \varsigma)$ recorrieran las calles de la ciudad cantando y pidiendo que se contribuyera a las fiestas del dios. A los atenienses les gustaba colgar estas eiresionai en las puertas de sus casas hasta el año siguiente (Rose, H. J., 1959, 75; Nilsson, M. P., 1967, 123). 


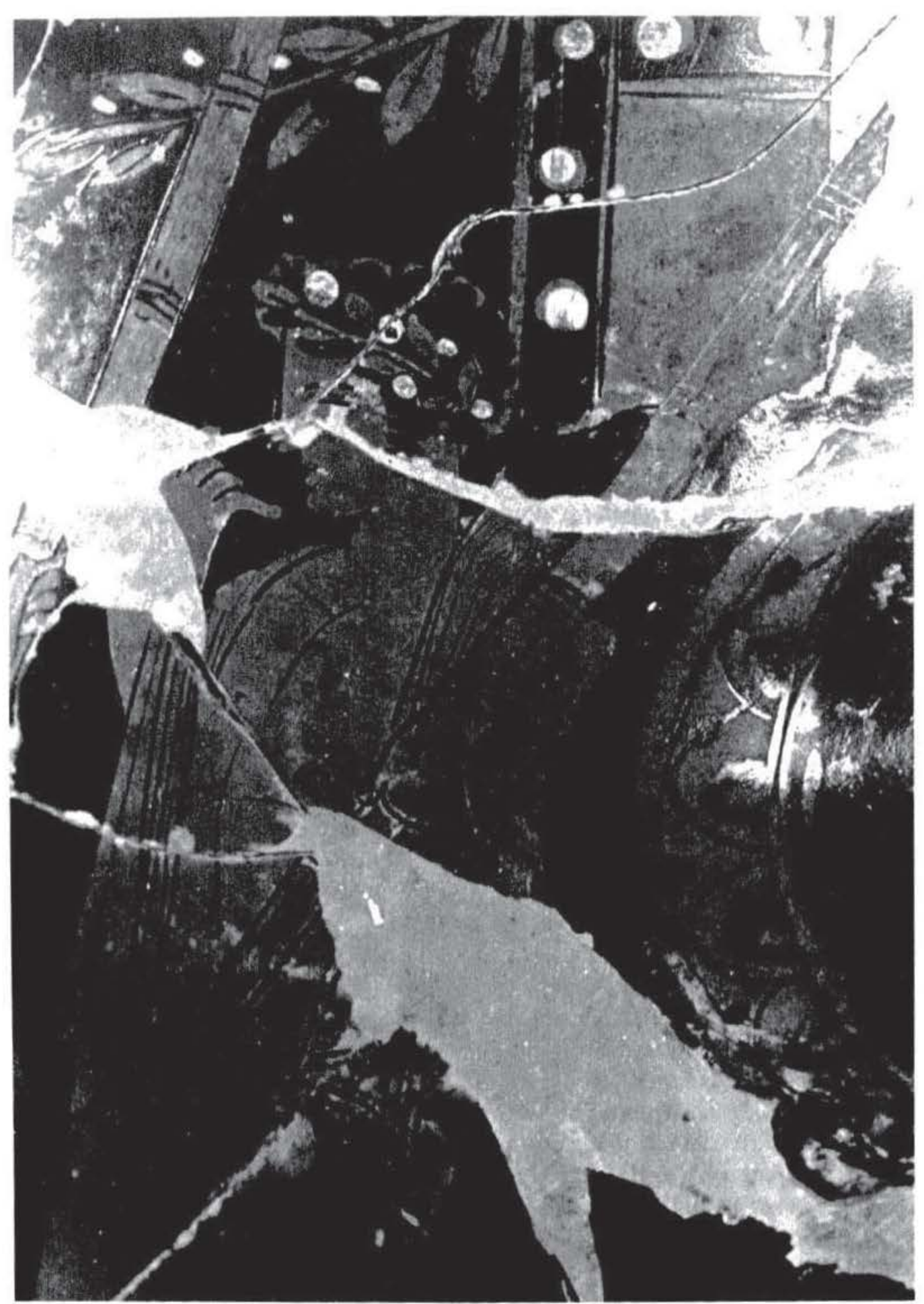

Figura 4.-Crátera núm. 1. Detalle de la puerta del templo con la rama de laurel. (Foto J. L. Montero). 


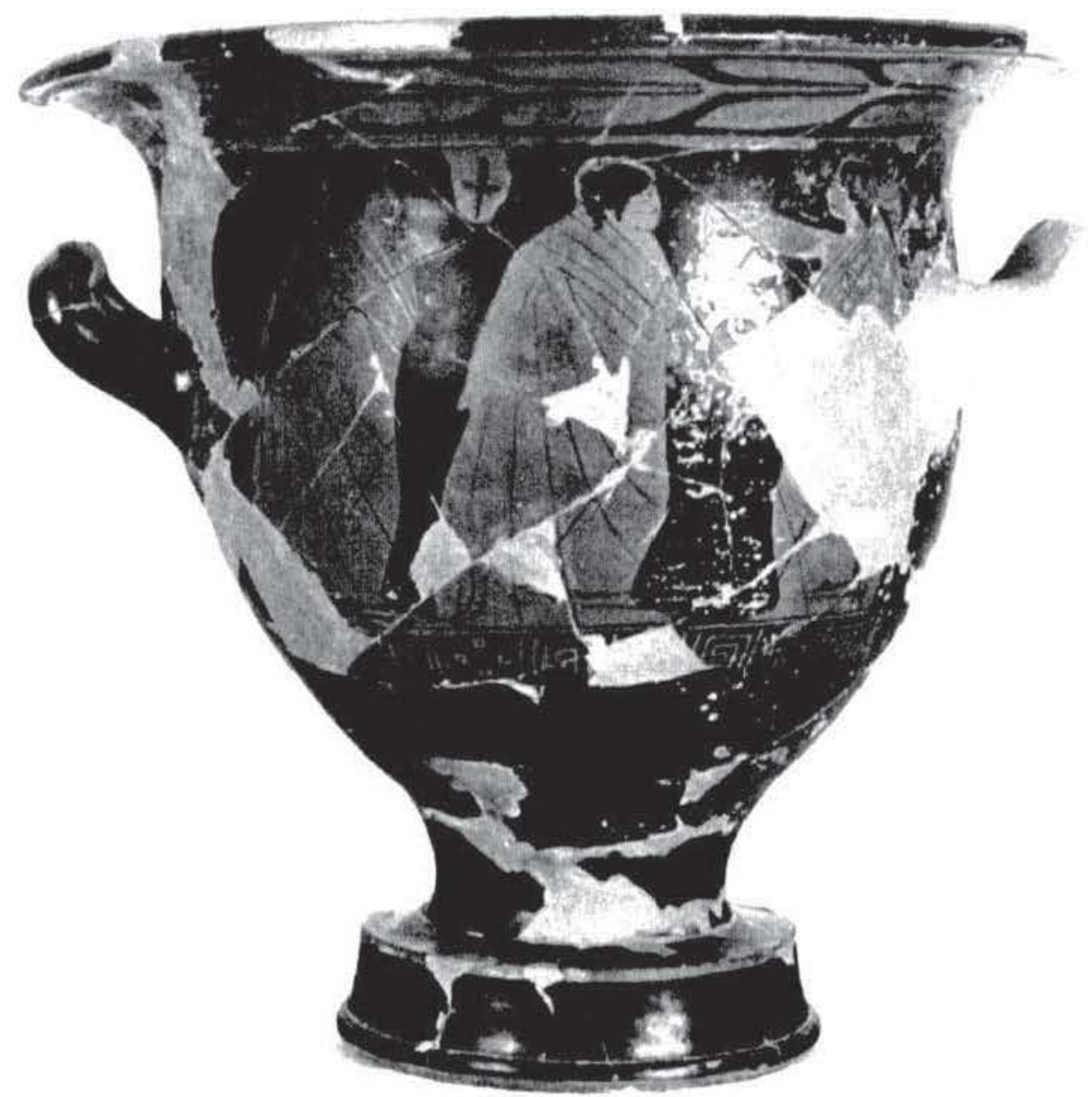

Figura 5.-Crátera núm. 1. Reverso. Escena de palestra. (Foto J. L. Montero).

\section{CiClo diOnisiaCo}

\subsection{Simposio}

Número 3. Crátera ática de campana de figuras rojas. Reconstruida y restaurada. Muy fragmentada (sesenta trozos), le falta la mayor parte de la escena del reverso, parte del borde y las asas. Dimensiones: $\mathrm{h}=390 \mathrm{~mm}$.; $\mathrm{hp}=50 \mathrm{~mm}$.; $\mathrm{db}=420 \mathrm{~mm}$; $\mathrm{dp}=190 \mathrm{~mm}$. Pintor del Tirso Negro. Segundo cuarto del siglo IV a. C.

Barniz negro brillante, bien adherido, con reflejos metálicos. Pasta anaranjada, compacta, blanda, bien depurada. Hojas de laurel en el labio exterior del borde. Queda en reserva una línea debajo de este friso y otra en el arranque del labio. Igualmente reservados el interior del pie, la unión del pie con el cuenco y en la parte inferior de la moldura del pie. Un friso de ovas en el arranque de las asas. Debajo de éstas, dos palmetas superpuestas circundadas por róleos. En la parte inferior de la escena un friso continuo formado por grecas y ajedrezado en proporción tres a uno. 


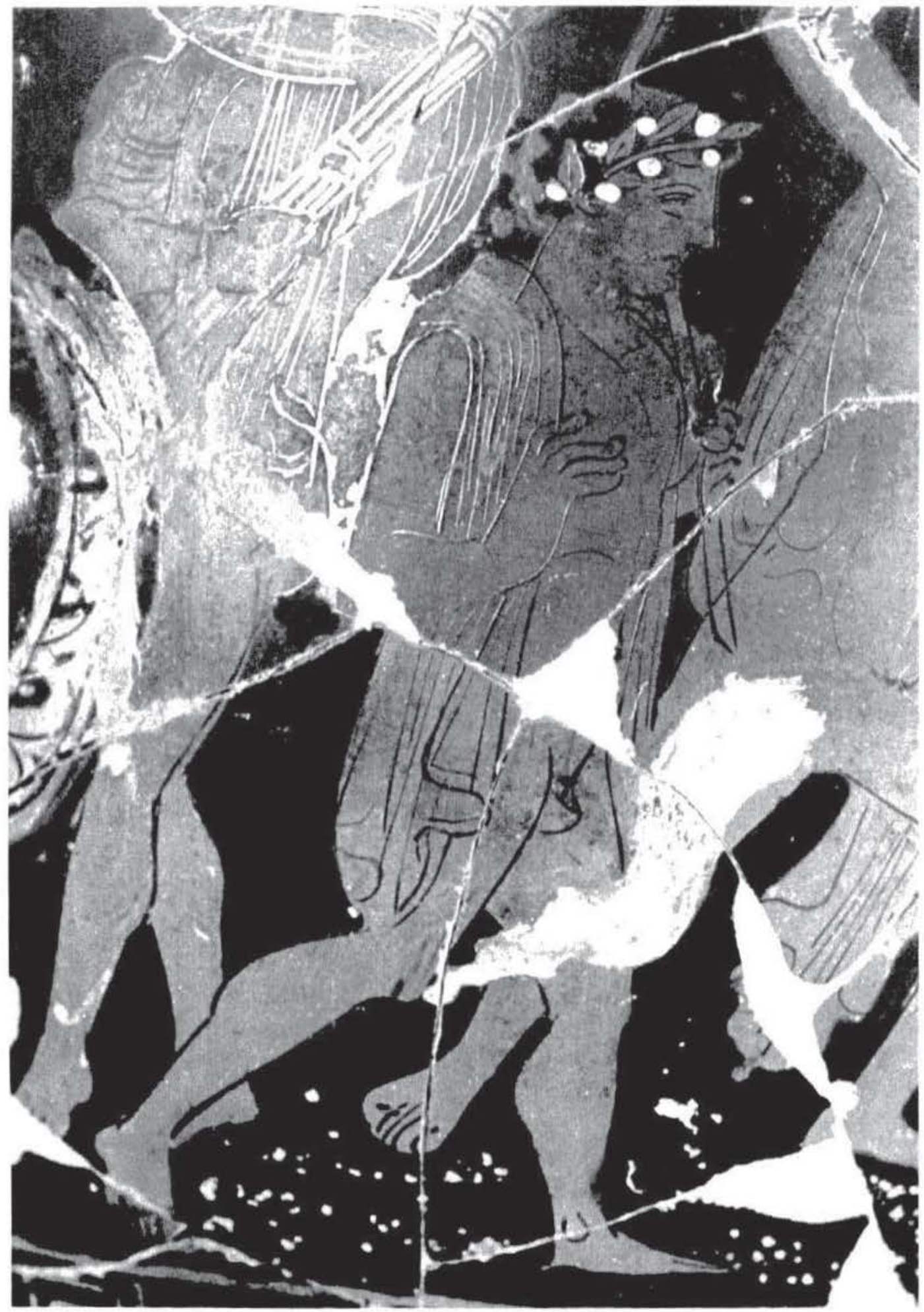

Figura 6. Crátera núm. I. Detalle (Foto J. L. Montero). 
a) Escena de simposio dionisiaco (figura 7). In ef centro aparece un hombre joven, imberbe, desnudo, sentado. Lleva los cabellos ordenados en bucles, una corona en pintura blanca y un gran tirso en la mano derecha. Debe identificarse con Dioniso. A la derecha aparece una dama sentada. Ariadna, con la mirada crusada con la del dios y el cuerpo orientido hacia la derecha. Presenta las carnaciones y el torso en pintura blanca sobrepintada, reseñando los detalles en tonos dorados. La parte inferior del ropaje con multitud de pliegues. Va tocada con una diadema decorada con puntos blancos. El cabello está recogido en una cola, cayéndole un bucle por encima de la oreja. Los brazos tendidos sobre las piernas. No se observa donde apoyan los pies, ni dónde están sentados, quedando suspendidos en el aire. Alrededor de la pareja se dispone la comitiva. Hacia la izquierda del dios una ménade le ofrece dos platos con frutos. Viste un peplos con numerosos pliegues que caen en dos niveles. Las carnaciones en pintura blanca sobrepintada. Le falta parte del cuerpo. A su lado un sátiro desnudo cierra la escena. Está de espaldas a la escena principal, aunque da la impresión de que se vuelve hacia la ménade. La mano que se conserva está mal concebida, sólo tres dedos. Está muy incompleto. Un pandero en el suelo entre el sátiro y la ménade.

A la derecha de la pareja de dioses se encuentra otro sátiro desnudo parcialmente oculto tras

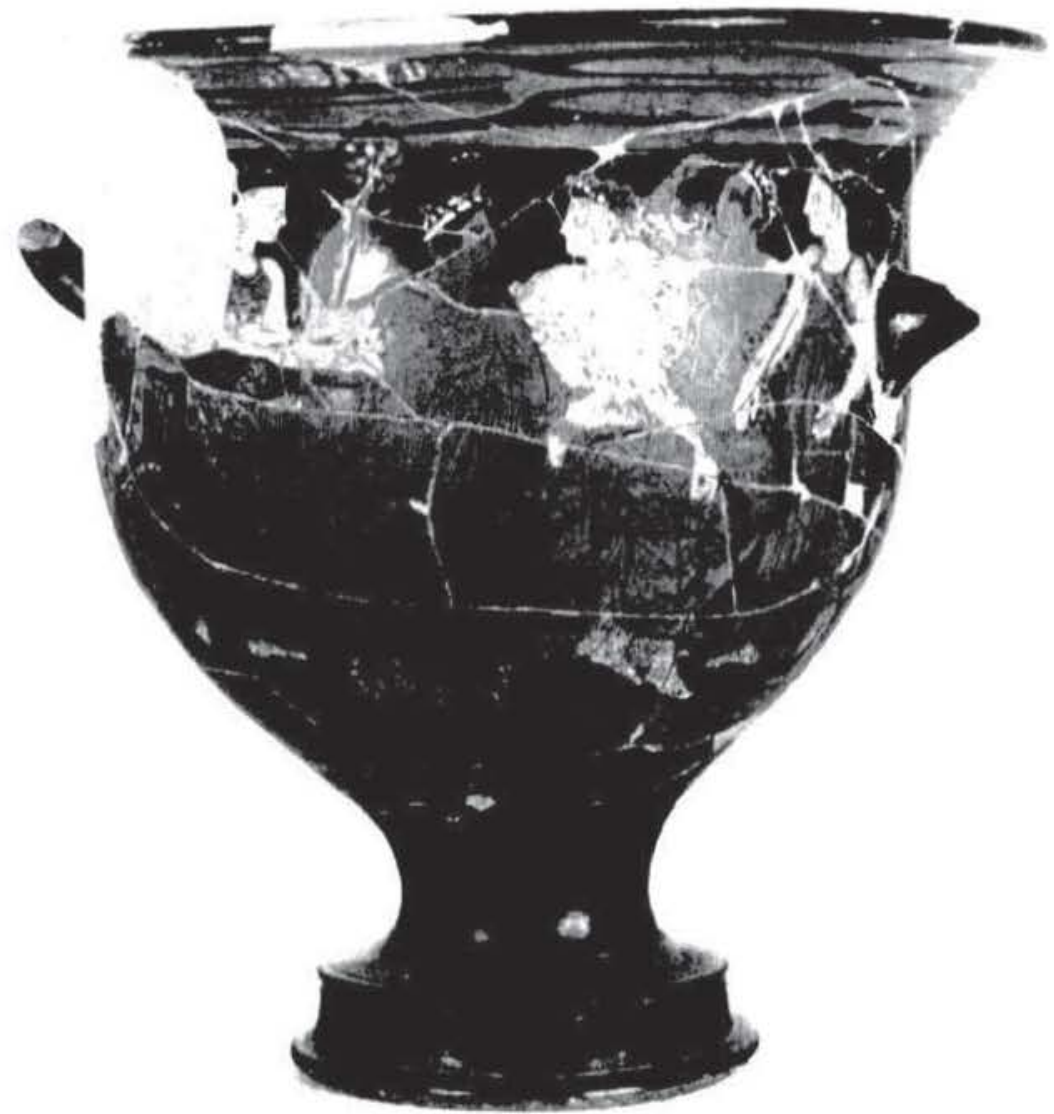

Figura 7.-Crátera núm. 3. Escena de simposio dionisiaco. (Foto J. L. Montero). 
Ariadna: adelanta una pierna y lleva tocado en pintura blanca. La musculatura se reseña con breves trazos. Cierra la escena por este lado otra ménade, orientada hacia la izquierda. con los brazos extendidos hacia adelante. Estos son desproporcionadamente grandes. Va adornada con los mismos detalles que la ménade ya descrita.

b) Se conserva muy fragmentariamente (figura 8). Se observan restos de tres efebos con grandes himátia. Los pliegues se señalan muy esquemáticamente. El de la derecha lleva diadema en pintura blanca, el de la izquierda adelanta un brazo que parece sujetar un disco. El central apenas se ha conservado.

\subsection{Thiasos Báquico}

Número 2. Crátera ática de campana de figuras rojas. Fragmentada, reconstruida y restaurada. No conserva el pie ni parte del borde. 45 fragmentos. Dimensiones: $\mathrm{hc}=270 \mathrm{~mm}$., $\mathrm{db}=350 \mathrm{~mm}$. Pintor del Tirso Negro. Segundo cuarto del siglo IV a. C.

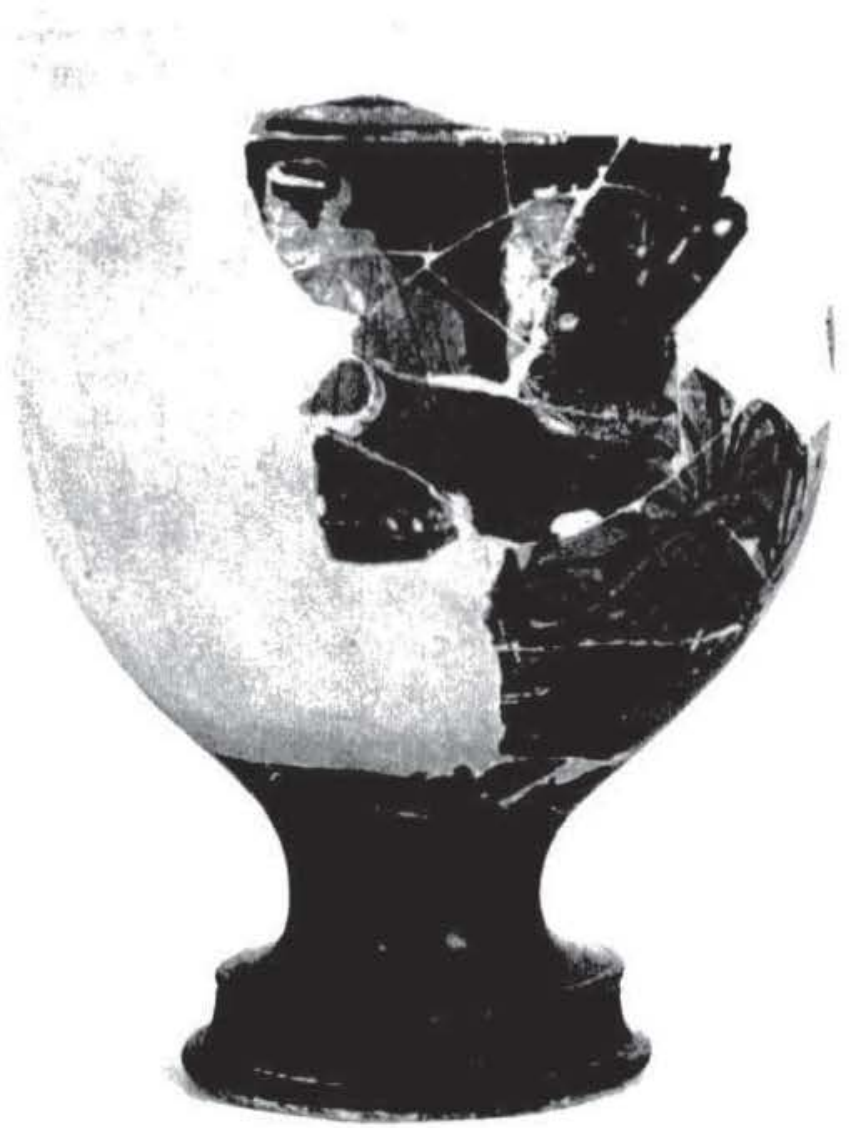

Figura 8.-Crátera núm. 3. Reverso. Restos de la escena de palestra. (Foto J. L. Montero). 
Barniz negro profundo, oliváceo, con reflejos rojizos en algunas partes, muy suave. Pasta anaranjada, blanda, depurada y compacta. Exterior: en el borde hojas de laurel hacia la izquierda, formando un friso continuo enmarcado por una acanaladura que queda en reserva. En el interior del borde dos líneas en reserva.

Ovas en los arranques de las asas. El espacio interno entre éstas queda barnizado de negro. La parte inferior de la escena la delimita un friso de grecas y ajedrezados.

a) Escena de cortejo dionisiaco (figura 9). La escena principal recoge el tema de Dioniso con una danzante (Ariadna ?) y dos sátiros en ambos extremos. En el centro se encuentra Dioniso desnudo caracterizado como un joven imberbe, con los cabellos en bucles y una corona de hojas y fruto blanco. Se dirige hacia la izquierda, con la cabeza vuelta hacia la ménade. Entre ambos un thytón en el suelo. Lleva una clámide colgada del hombro derecho que le cae por detrás del cuerpo. Este brazo es alzado en tanto que con el otro mantiene un tirso ricamente adornado con frutos y flores de pintura blanca sobrepintada.

A la derecha aparece una ménade en éxtasis, íntegramente en pintura blanca, con los detalles reseñados en tonos dorados. Presenta la cabeza levantada hacia atrás, con un gran pandero en la mano derecha. Lleva la melena suelta con adornos que le caen por la espalda.

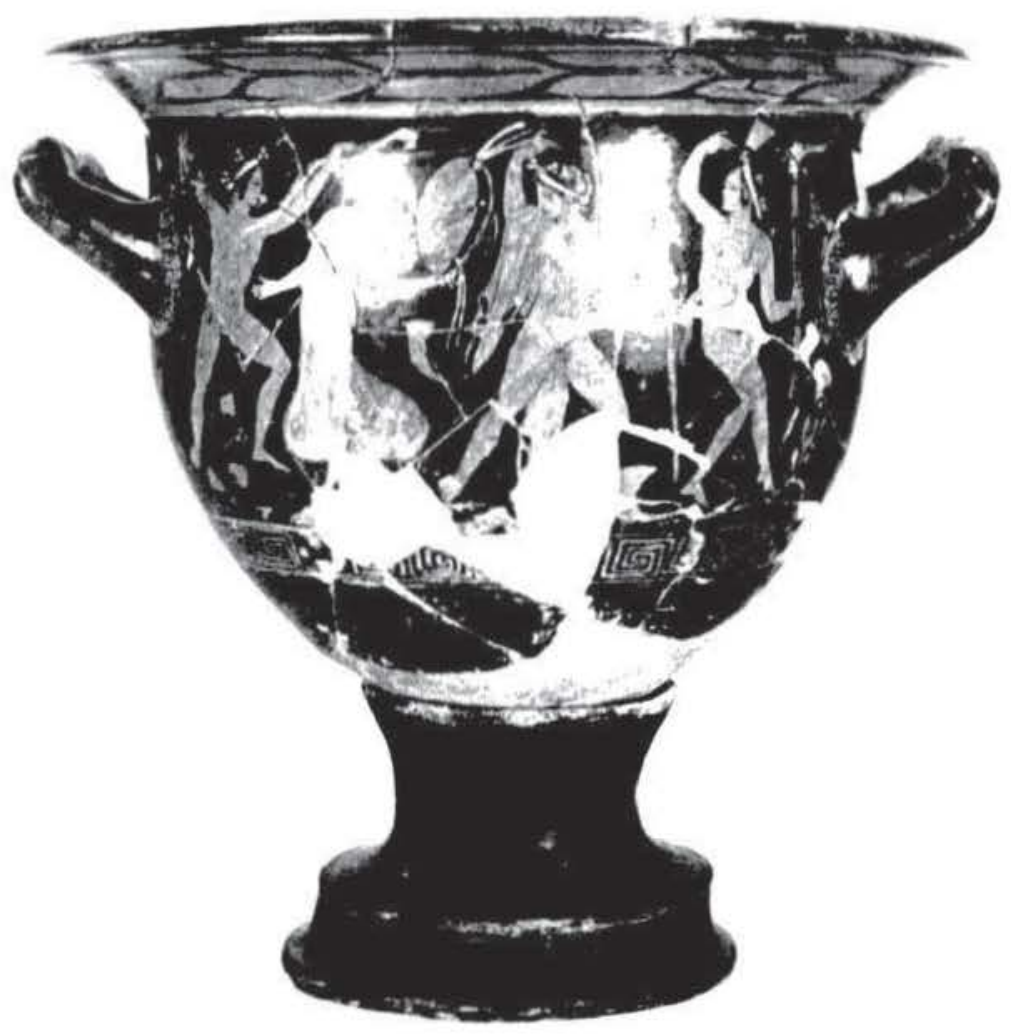

Figura 9.-Crátera núm. 2. Escena de Thíasos dionisiaco. (Foto J. L. Montero). 
Completan la escena dos sátiros situados en los extremos. ambos desnudos y con diadema. El de la izquierda se aproxima a la ménade con los brazos en alto, llevando una cinta representada en pintura blanca entre sus brazos. El otro parece invitar a la dan/a. con su brazo derecho levantado. mientras el i/quierdo mantiene una gran antorcha, con la llama en pintura blanca sobrepintada. La parte inferior de la escena presenta elementos que la sitúan en un paisaje agreste. Entre las figuras se colocan hojas de hiedra y frutos en pintura blanca diluida.

b) Tres efebos con grandes himátia que les llegan a los pies (figura 10). El de la izquierda y el central, ambos parcialmente conservados se dirigen hacia la derecha: el primero muestra un disco en su mano, el otro extiende un brazo hacia adelante. Frente a ellos está el tercero, en el lado derecho, separado por una columna. Los detalles anatómicos de los tres personajes son muy sumarios y esquemáticos, lípicos de las escenas de reverso de este período.

Número 7. Crátera ática de campana de figuras rojas. Se conservan 63 fragmentos, aunque está muy incompleta. Le falta la base y el pie completamente así como un asa, parte del borde y cuerpo. DM $=250 \mathrm{~mm}$. por $163 \mathrm{~mm}$. Pintor del Tirso Negro. Segundo cuarto del siglo IV a. C.

Barniz negro brillante con irisaciones metálicas. En el reverso, barniz con tonos rojizos. Pasta dura y compacta de color anaranjado.

Exterior: bajo el labio del borde una pequeña moldura en reserva que enmarca un friso de

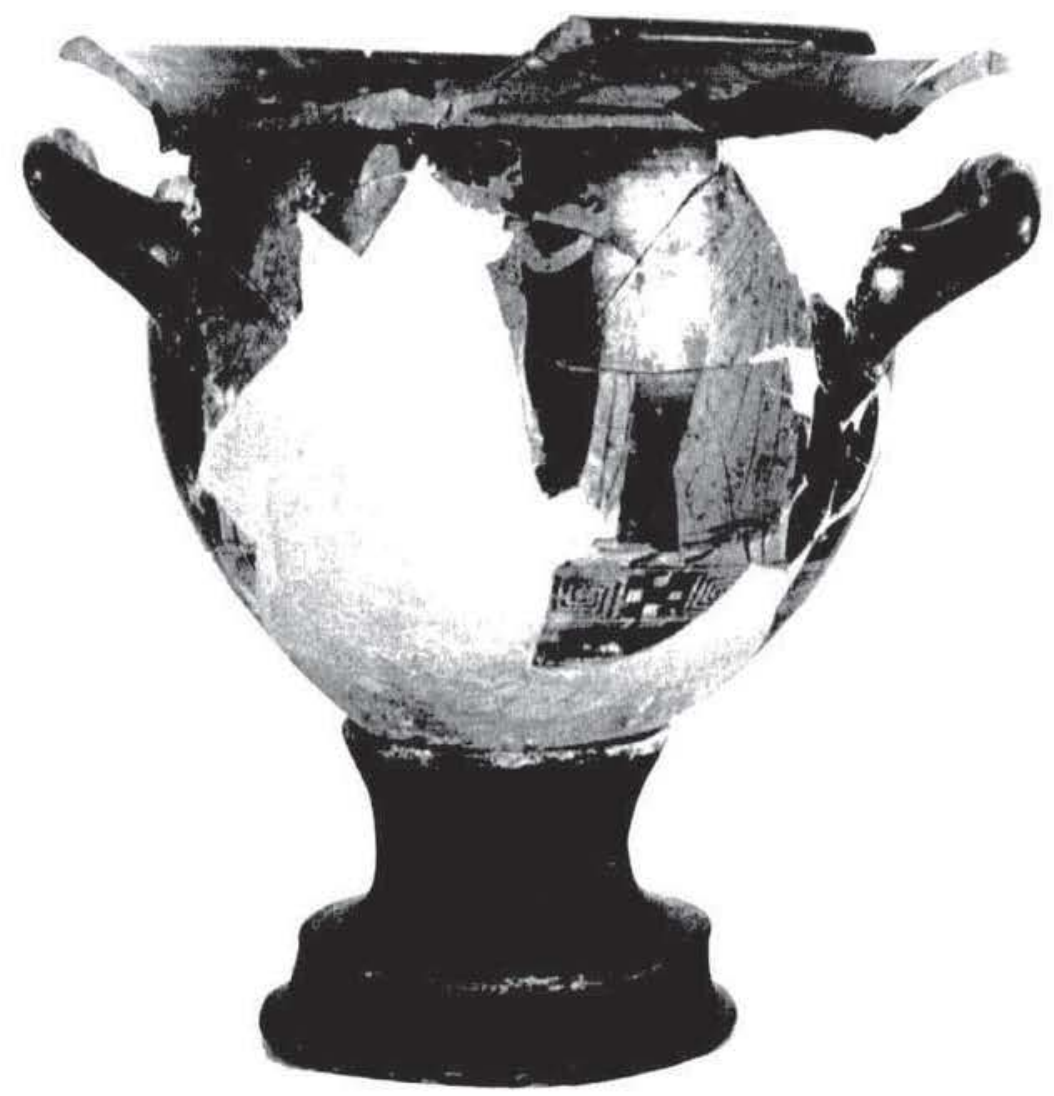

Figura 10.-Crátera núm. 2. Reverso. Escena de palestra (Foto J. L. Montero). 
hojas de laurel hacia la isquierda. Debajo de estas otra franja reservada que ha sido afectada al realizar la composición figurada principal.

a) Escena dionisiaca (figura 11). Está formada por cinco figuras bastante incompletas. En el centro un personaje femenino con el pelo recogido y las carnaciones en pintura blanca, que mira hacia la izquierda. Con su mano derecha sostiene el péplos, Los detalles de éste. collares y rizos de pelo que le cuelgan por la cara asi como los ojos y la boca están hechos con pintura blanca diluida, con tonos dorados. Pudiera ser Ariadna. Sostiene con la palma de la mano isquierda una phicala en blanco. A su lado Dioniso, quizis sentado, también hacia la irquierda, con una corona de hojas de hiedra y puntos blancos. Sostiene un gran tirso. Delante de él aparece Eros, con las carnaciones en blanco, del que se conserva el ala izquierda. Por último otra ménade vestida con peplos sentada junto a Dioniso y apoyada en un pandero. Frente a ella otro joven desnudo, seguramente un sátiro completa la escena. apoyando su brazo derecho ya en la parte del asa de la crátera. Detrás de Ariadna otro sátiro bailando que se dirige hacia la derecha. pero que está vuelto hacia ella a la que saluda con el brazo derecho en alto. La mano está mal concebida y con seis dedos. El sátiro va desnudo y le cuelgan restos de la nébride. Del techo cuclgan varios pámpanos o racimos de uvas. La escena está adornada con abundantes tallos de hiedrat en pintura blanca diluida.

b) Escena de palestra (figura 12). Muy incompleta. Se conservan restos de tres jóvenes completamente envueltos en sus himaitia. Estos están señalados por varias líneas finas de bar-

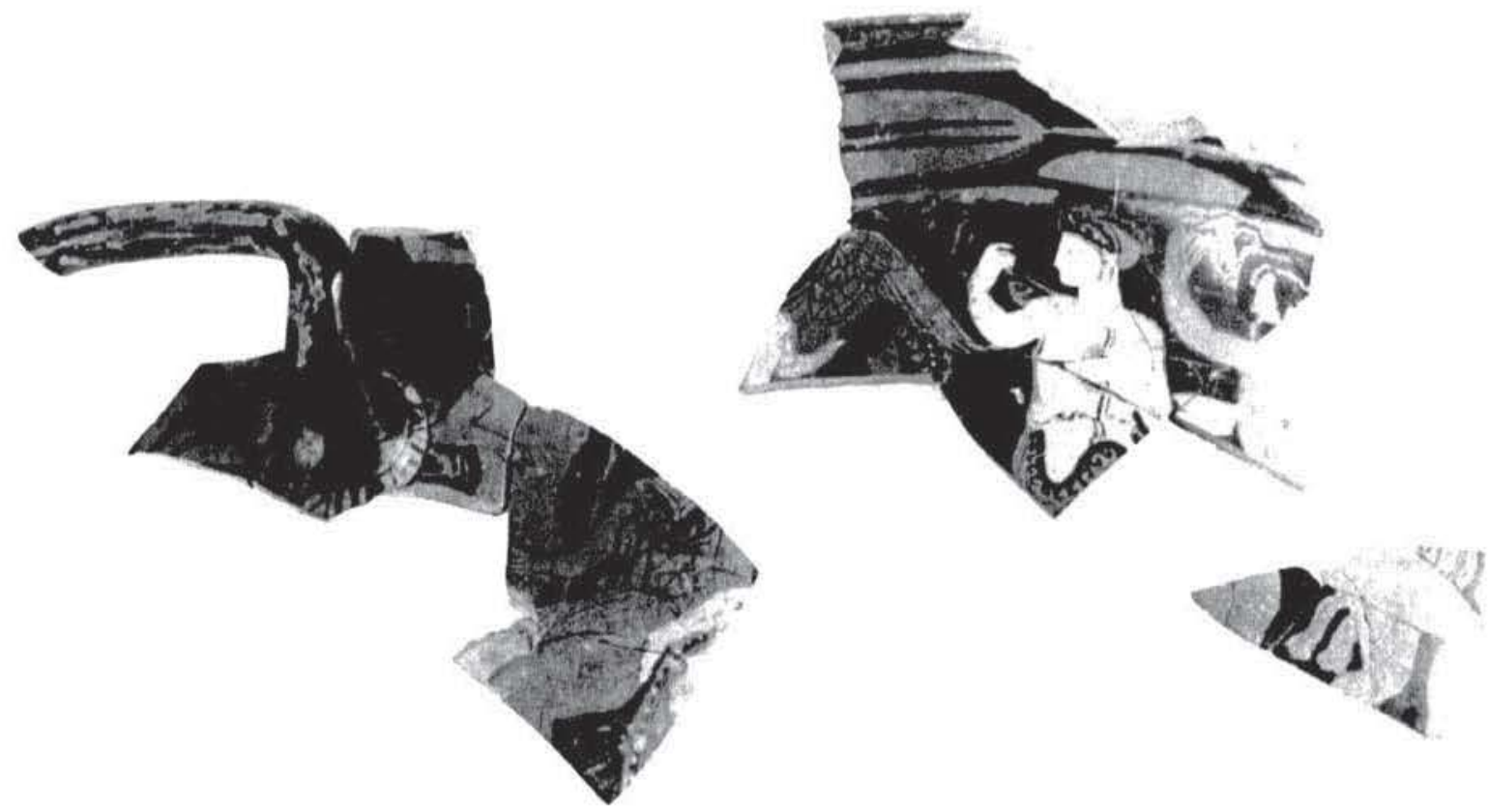

Figura 11.-Crátera núm. 7. Escena de Thíasos dionisiaco. (Foto J. L. Montero). 
niz. Dos de los jovenes se dirigen hacia la derecha, donde el tercero dialoga con ellos de frente. Del techo cuelgan pequeñas cintas en pintura blanca.

Los personajes estan dibujados de manera sumaria, de forma que en el primero de la izquierda unicamente una mancha de barniz forma el cabello, pero no se dibujan los ojos, la boca... En los otros jóvenes finas líneas de barniz diluido simulan los ojos, nariz, boca. Falta la parte inferior de la escena.

Numero 8. Crátera ática de campana de figuras rojas. Incompleta. Se conservan sesenta fragmentos. Le falta el pie, las asas y parte del borde y cuerpo. Está parcialmente quemada. DM = 293 por $162 \mathrm{~mm}$.

Barniz negro brillante, adherente, con irisaciones metálicas, tacto suave. El exterior muy picado. Pasta anaranjada, bien depurada, grano muy fino. Pintor del Tirso Negro. Segundo cuarto del siglo Iv a. C.

Exterior: en la boca hojas de laurel hacia la izquierda: en la unión del cuerpo con la boca una pequeña acanaladura sin barnizar. Debajo de la escena figurada franja de grecas y un aspa.

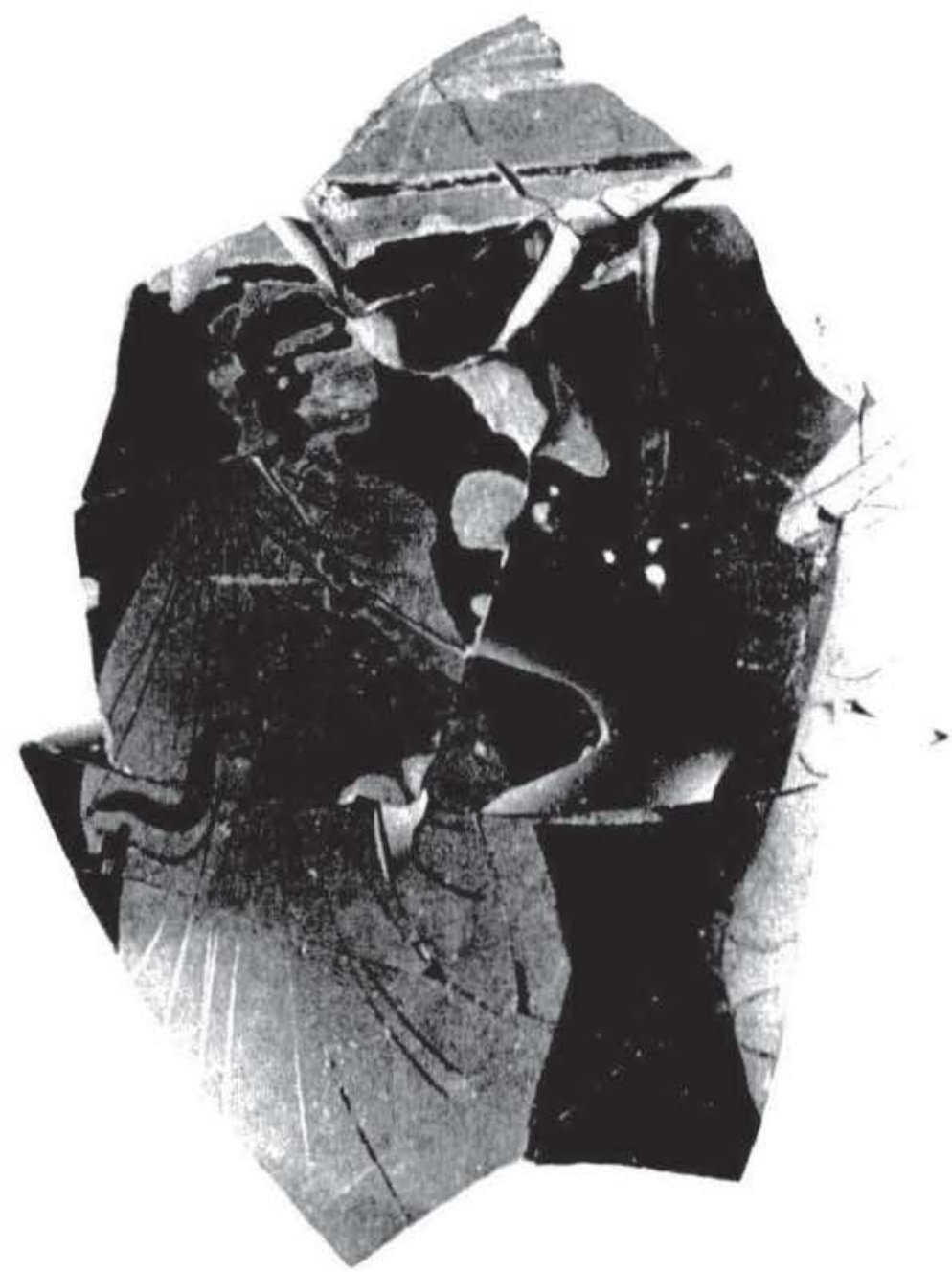

Figura 12.-Crátera núm. 7. Reverso. Escena de palestra. (Foto J. L. Montero). 
a) Escena de sátiros y ménades (figura 13). En el centro una ménade dan/ando se dirige hatcia la derecha, vestida con un peplos y las carnaciones en pintura blanca: de un hombro le cuelga la nébride adornada por puntos negros.

Lleva el cabello recogido por una banda de puntos blancos; con la mano derecha sujeta un tirso, ricamente decorado con puntos blancos. Debajo de éste un pandero.

A la izquierda aparece un sátiro barbado, en escorzo, se dirige hacia la izquierda, pero vuelve la cabeza hacia la derecha, mirando a la ménade. Va tocando el aulís. Ante él otro tirso. un rhytón y un pandero colgado del techo. Cierra la escena por este lado otra ménade. Se observan los pliegues del peplos y restos de una néhride. Tiene las carnaciones blancas, va descalza. En el otro extremo de la escena otro sátiro incompleto, con las piernas abiertas, se dirige hacia la

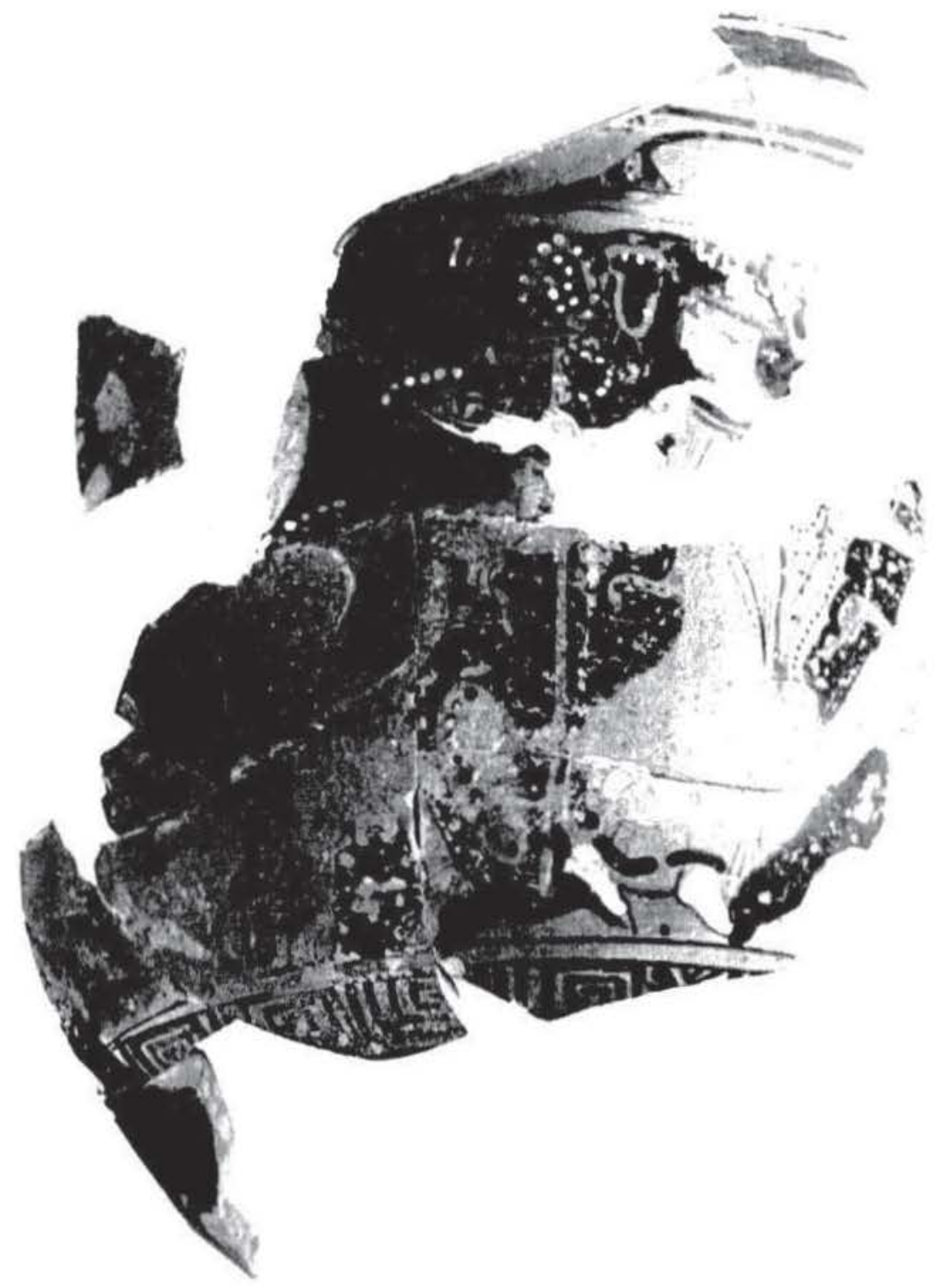

Figura 13.-Crátera núm. 8. Escena de sátiros y ménades. (Foto J. L. Montero). 
derecha. De la parte superior de la escena. cuelgan pámpanos con puntos blancos y varias líneas blancas entre los personajes. La base de la escena la forman varias rocas que le confiere un caricter de naturale/a campestre.

b) Escena de palestra (figura 14). Tres jovenes envueltos en amplios himatia. El de la isquierda lleva un disco en la mano. que muestra al personaje de la derecha, vuelto frente a los otros. Los mantos les cubren hastat los pies. Los pliegues están marcados por finas lineas de barnis bastante diluido, Los detalles anatómicos son muy someros. El pelo es una mancha de barnis. los ojos dos líneas, y la boca un punto. Se apoyan en un friso de grecas con un aspa.

Es éste uno de los temas preferidos de las cerámicas griegas del siglo IV a. C.. y uno de los habituates de la cerámica ática decorada que suele encontrarse en los yacimientos ibéricos peninsulares de este periodo. En nuestro caso se cumple nuevamente esta norma ya que la mitad de nuestras cráteras, es decir cuatro ejemplares, están decorados con motivos referentes a este dios. Tres de ellas - números 2, 7,8 - exhiben escenas de thiasos o cortejo, mientras que la otra-número 3 -ofrece un simposio.

\section{ESCENA DE BANQUETE}

En la crátera número 3 se observan seis personajes en un banquete o simposio. En el centro

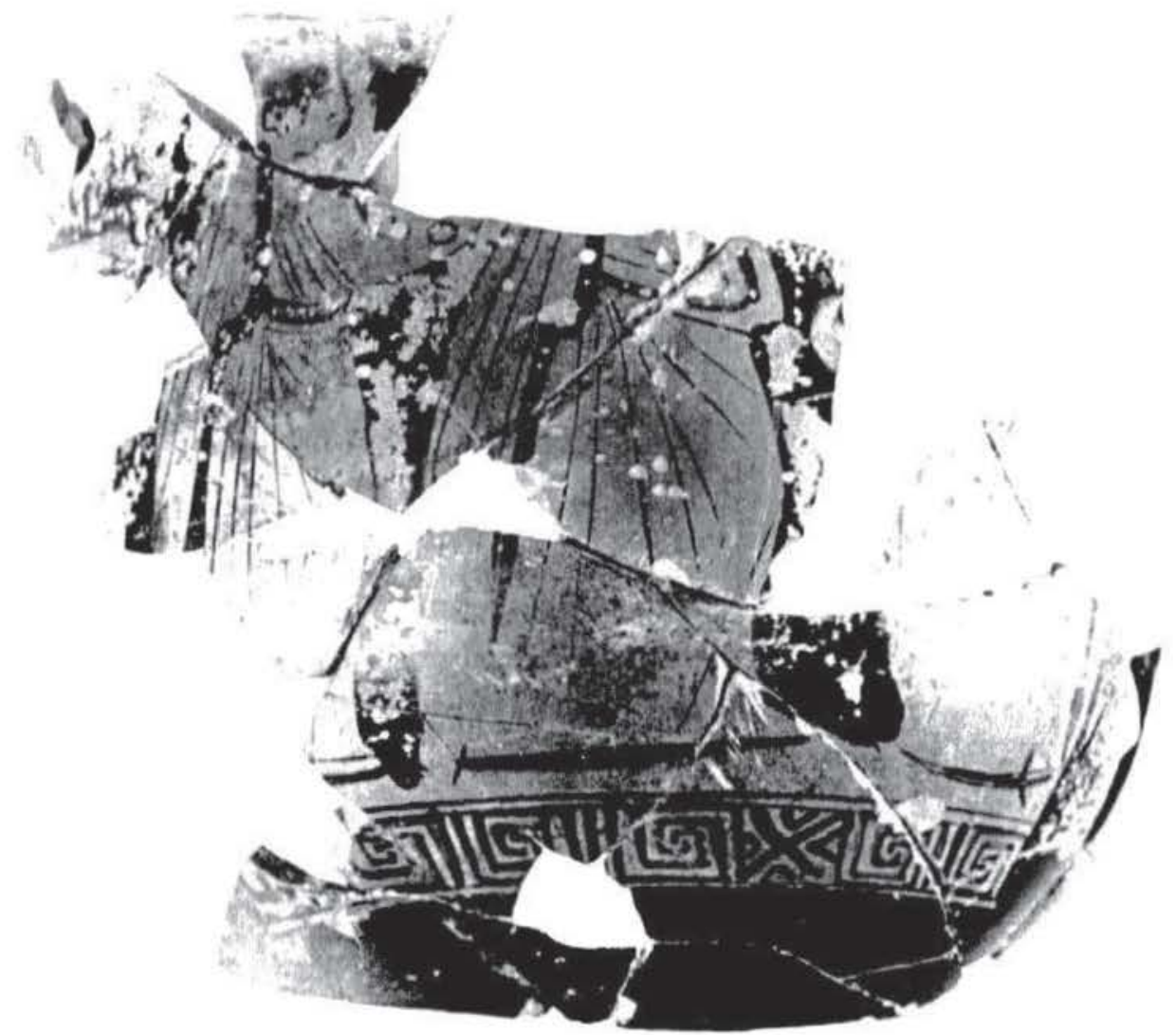

Figura 14.-Crátera núm. 8. Reverso, Escena de palestra. (Foto J. L. Montero). 
presidiendo la reunión aparecen recostados Dioniso y Ariadna con sus atributos característicos: tirso, coronas, joyas y también las carnaciones en pintura blanca en el personaje femenino. Por la derecha se aproxima una ménade que ofrece a la pareja frutos en una bandeja. La escena se completa con dos sátiros y otra ménade, dispuestos de manera que van alternándose personajes masculinos y femeninos.

El culto de Dioniso, dios del vino, la naturaleza y la fertilidad, vinculado por tanto con los cultos de Eleusis, cobra un inusitado interés en la sociedad griega desde las últimas décadas del siglo V a. C., auge que se incrementó en los primeros años del siglo IV a. C., ya que pese a su incorporación a la polis se mantuvo como un dios campesino (García López, J., 1975, 123).

Este esplendor se refleja inmediatamente en las representaciones de la cerámica ática del siglo IV a. C., en donde se convierte en uno de los temas predilectos de los ceramistas junto con los ciclos de Apolo, Afrodita y Eros (Metzger, H, 1951, 101-154). Los temas elegidos son variados: nacimiento e infancia, su encuentro en Naxos con Ariadna, quien desde ese momento se convertirá en su compañera, o bien representaciones de la pareja de amantes acompañados por el cortejo báquico, esto es, sátiros, silenos y ménades que bailan y danzan, o bien escenas de banquetes en los que los participantes suelen ser los mismos. En todas ellas Dioniso y Ariadna se sitúan en el centro de la imagen (Metzger, H., 1951, 123). Dioniso suele estar tratado como un dios joven e imberbe, con los cabellos ordenados en bucles, generalmente coronado. Aparece desnudo y puede llevar el himátion colgado en un brazo. Suele acompañarse con un gran tirso (Villanueva Puig, M. C., 1989, 304) a partir del final del clasicismo su aspecto pasa a ser un tanto afeminado (Boardman, J., 1989, 225).

Del cortejo junto a los sátiros normalmente desnudos, seres de la naturaleza que acompañan al dios en sus manifestaciones, es importante destacar a las ménades, ya que imponen una revolución al propiciar la salida de la mujer del habitual gineceo en el que estaba recluida en la sociedad griega, al mundo exterior en igualdad con el hombre. Las ménades eran elemento fundamental en la configuración del rito tal y como nos ha transmitido Eurípides en sus Bacantes.

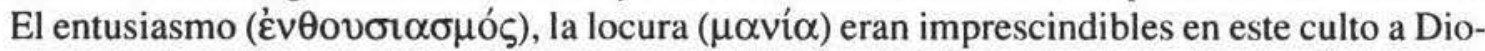
niso que distinguían a sus adoradores de otros ritos. La divinidad se apoderaba de ellas con un frenesí incontrolado que era propiciado por la música de los timbales, flautas y crótalos que eran los instrumentos orgiásticos por excelencia de los griegos (Dodds, E. R., 1986, 254), en ese momento de comunión mística con la divinidad se producía el éxtasis, aunque fuera pasajero (García López, J., 1975, 251-259).

Estas representaciones son bastante abundantes en la Península Ibérica en la primera mitad del siglo IV a. C. Se conocen ejemplares en Ampurias (Trías G., 1967, 177, núm. 575, lámina XCVI) necrópolis de La Albufereta (Alicante) (Trías, G. 1967, 367, núm. 10, lámina CLXXIII) Toya (Trías, G. 1967, 462, núm. 8, lámina CCXII) y Castellones de Ceal en Jaén (Trías, G., 1967, 478, lámina CCXXXVIII), Baza (Presedo, 1982, 278-281, figura 192-1 y 193-1, láminas XXXI-1 a 4.), Pecio del Sec (Trías, G., 1987, 55-56, núm. 1 a 5 y 8, láminas 1,4 y 5 ) y en el Cabecico del Tío Pío, Archena (García Cano, J. M., Page V., 1990) todas ellas correspondientes al Tirso Negro, excepto la de La Albufereta.

\section{ESCENAS DE THIASOS}

La crátera número 7 pese a lo fragmentado de su conservación, se puede reconstruir fácilmente la escena principal. En el centro aparece la pareja de amantes, Dioniso como joven im- 


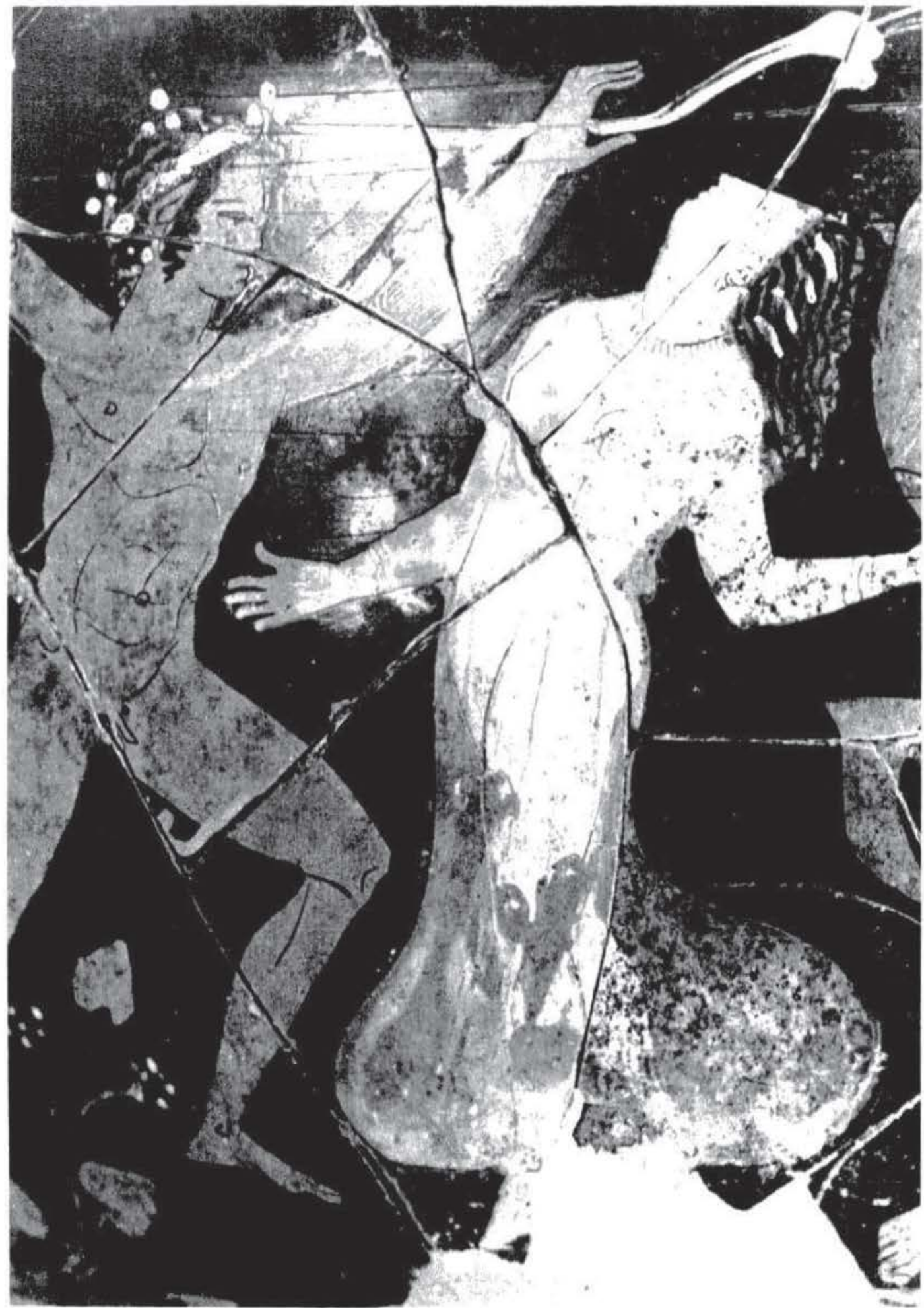

Figura 15.- Crátera núm. 2. Escena de Thíasos dionisiaco. Detalle de ¿Ariadna? danzando. (Foto J. L. Montero). 
berbe del que sólo se conserva la cabeza coronada de hojas de hiedra y perlas, que debía estar sentado, con su tirso a la derecha y Ariadna situada a su izquierda, de pie, con las carnaciones en blanco, y sostiene una phiala para libar en su mano izquierda, mientras que con la derecha parece que quiere taparse la cara con su velo en un gesto típico de recato femenino o aidós, en una ambivalente actitud de enkálypsis o anakálypsis (desvelación) tan del gusto del mundo griego y oriental desde siglos atrás (Olmos, R. y B. de Griñó, 1985 41-42, con la bibliografía pertinente; existe un vaso ibérico con la representación de una anakálypsis procedente del poblado de Santa Catalina del Monte (Verdolay), conservado en el Museo de Murcia. Véase: Jorge Aragoneses, M., 1969, 200-204). Ambos enamorados miran hacia la derecha donde está situado Eros que indica que el amor existente entre el dios y la mortal preside el momento. Completan la imagen dos sátiros y una ménade.

La crátera número 8 muestra igualmente otro instante de fiesta dionisiaca y aunque incompleta, presenta a una ménade con las carnaciones en blanco, coronada y con un tirso en su mano derecha, que quizás sea Ariadna; se dirige hacia su izquierda escoltada por dos sátiros, uno de los cuales toca un aulós. Hacia la izquierda del vaso se aprecia otra ménade que lleva una nébride encima del peplos. La escena se completa con múltiples detalles que nos introducen en el mundo dionisiaco, tales como tímpanos, cuernos de la abundancia, racimos de uva, siendo la base de la misma muy rugosa, con piedras de distinto tamaño que configuran pendientes que muestran lo agreste del paisaje donde se desarrollan los mitos.

La número 2 mejor conservada que las precedentes, presenta una escena de danza estática con sólo cuatro personajes. Los dos centrales pueden ser Dioniso, desnudo, con un rico tirso en su mano derecha, que contempla las convulsiones de su pareja, Ariadna (figura 15), que aparece con las carnaciones en blanco con collares y otras joyas. Esta mueve la cabeza dejando caer su melena suelta hacia atrás, dando la impresión de que en total éxtasis, recuerda con esta actitud uno de los pasajes de las Bacantes de Eurípides en el que se dice "yo haré que dejes de sacudir el pelo hacia atrás». (Tovar, A., 1960, 241).

La escena se completa con dos sátiros en los extremos junto a las asas. Uno se dirige hacia Ariadna, mientras que el segundo contempla los movimientos de ésta en el otro extremo de la acción, iluminando el cortejo con una antorcha en su mano derecha.

Los reversos de las tres cráteras exhiben escenas esterotipadas de palestra, con grupos de jóvenes sumariamente ejecutados envueltos en amplios mantos que contribuyen a distorsionar todavía más la imagen. Los jovénes dialogan entre sí, generalmente suelen representarse dos o tres, y pueden llevar un estrígilo o un disco en la mano, otras veces se muestra también al maestro que puede llevar un bastón. Estas imágenes de gimnasio tienen también connotaciones de iniciación a la homosexualidad (para un análisis exhaustivo de estas caras B véase Trías, G., 1987, 57-60).

En la Península Ibérica es frecuente hallar cráteras de campana con esta clase de representaciones. En la Alta Andalucía hay tres procedentes de Galera (Granada) (Trías, G. 1967, 460462, láminas CCIX-CCX; García Cano, J. M., 1979-80, 232-233, lámina IV), cuatro de Baza (Presedo, J., 1982, 235-236, figura 192-194, y pág. 255, figura 21), otras seis de Toya y Villaricos (Almería) pertenecientes al Retorted Painter, y otra al Tirso Negro (Trías G. 1967, $467-$ 472, láminas CCXVIII, CCXX, CCXXX (Toya), y 439-442, láminas CXCVI, CXCIX (Villaricos). En Murcia la de la necrópolis de El Cigarralejo (Mula) (Cuadrado, E. 1958, 312-316) y Archena (García Cano, J. M. y Page, V., 1990). 


\section{OTROS TEMAS}

\subsection{CICLO DE HÉRCULES}

Número 6. Crátera ática de campana de figuras rojas. Incompleta, muy fragmentada, 52 trozos. $\mathrm{DM}=289 \mathrm{~mm}$. por $187 \mathrm{~mm}$. Segundo cuarto del siglo IV a. C.

No se conserva el borde, ni las asas. Debajo de éstas dos palmetas superpuestas, formadas por diez pétalos cada una y rodeadas por róleos. La escena se apoya sobre un friso de grecas y ajedrezados en una proporción de cuatro a uno. Este friso es continuo, da la vuelta a todo el vaso incluso debajo de las asas.

Barniz negro brillante, bien adherido en la superficie, con líneas en tonos rojizos y una banda sin barnizar que delimita el cuerpo de la crátera. Parcialmente picado en el exterior. Pasta de color naranja claro, fina, depurada, blanda y compacta.

a) Hércules conducido al Olimpo en una cuádriga por una Nike (figura 16). A la derecha de la escena se observa al auriga. Conduce la Nike, con el pelo recogido con una banda. La cabeza queda envuelta en un círculo de barniz negro. Las alas asoman por detrás, a ambos lados. Está toscamente conformada ya que la boca es un punto de barniz, los ojos están definidos por tres finas líneas y un punto. Su hombro izquierdo encaja muy apretado con el del personaje masculino situado a la derecha. Por detrás asoman varias ovas del friso que remata el arranque de las asas.

Ambos personajes están de perfil, dirigidos hacia la izquierda. En la parte inferior se observa la mayor parte de las dos ruedas de tres a cinco radios, y parte de los ejes del carro. Este va tirado por cuatro caballos al trote, con las patas delanteras levantadas. No se conservan las cabezas, sólo las crines de tres señaladas con rayitas paralelas de barniz negro. Debajo del cuello de los caballos llevan peto para el tiro, resaltado con pintura blanca. La concepción general es muy sumaria, formándose como un bosque de patas delanteras, alternadas con las traseras en. donde únicamente se definen las rodillas, los cascos y los sexos masculinos de los mismos.

Aunque sólo se conserva la mitad inferior de la crátera, el tema que representa se puede reconstruir prácticamente en su totalidad. Aparece una cuádriga conducida por una Nike, y a su izquierda un hombre desnudo de complexión atlética, Hércules, mostrado como un joven imberbe, que debe llevar la clava en su mano izquierda, apoyada en el antebrazo, tal y como suele representarse en otros vasos de este período con el mismo tema (Boardman, J., 1989, núm. 348 y 354).

Con la mano derecha agarra el asidero del carro. Los caballos marchan al trote; la victoria se concentra en la conducción del carro. Sólo se aprecia el inicio de las alas por detrás de sus hombros.

La imagen presenta el trasladc en una cuádriga conducida por una victoria de Hércules al Olimpo para proceder a su apoteosis y posterior divinización, después de haber sido inmolado en una pira funeraria. La escena se podría completar con Hermes como guía y mensajero de los dioses por delante de la cuádriga.

Hércules llegó a ser el más popular de los héroes mitológicos en Atenas, quizás por ser su protectora Atenea, quien también lo era de la ciudad (Boardman, J., 1988a, 221-225). Este tema dominó el repertorio en la cerámica ática de figuras negras, siendo representado en especial en la realización de los doce trabajos, sobre todo en las luchas contra monstruos y gigantes, o también su introducción en el Olimpo por parte de Atenea (Boardman, J., 1988 b, 226-228).

En las representaciones del siglo IV a. C. aparece únicamente el carro, mientras que en períodos precedentes el carro puede ser conducido por Atenea (Boardman, J., 1989, 228) o por Io- 


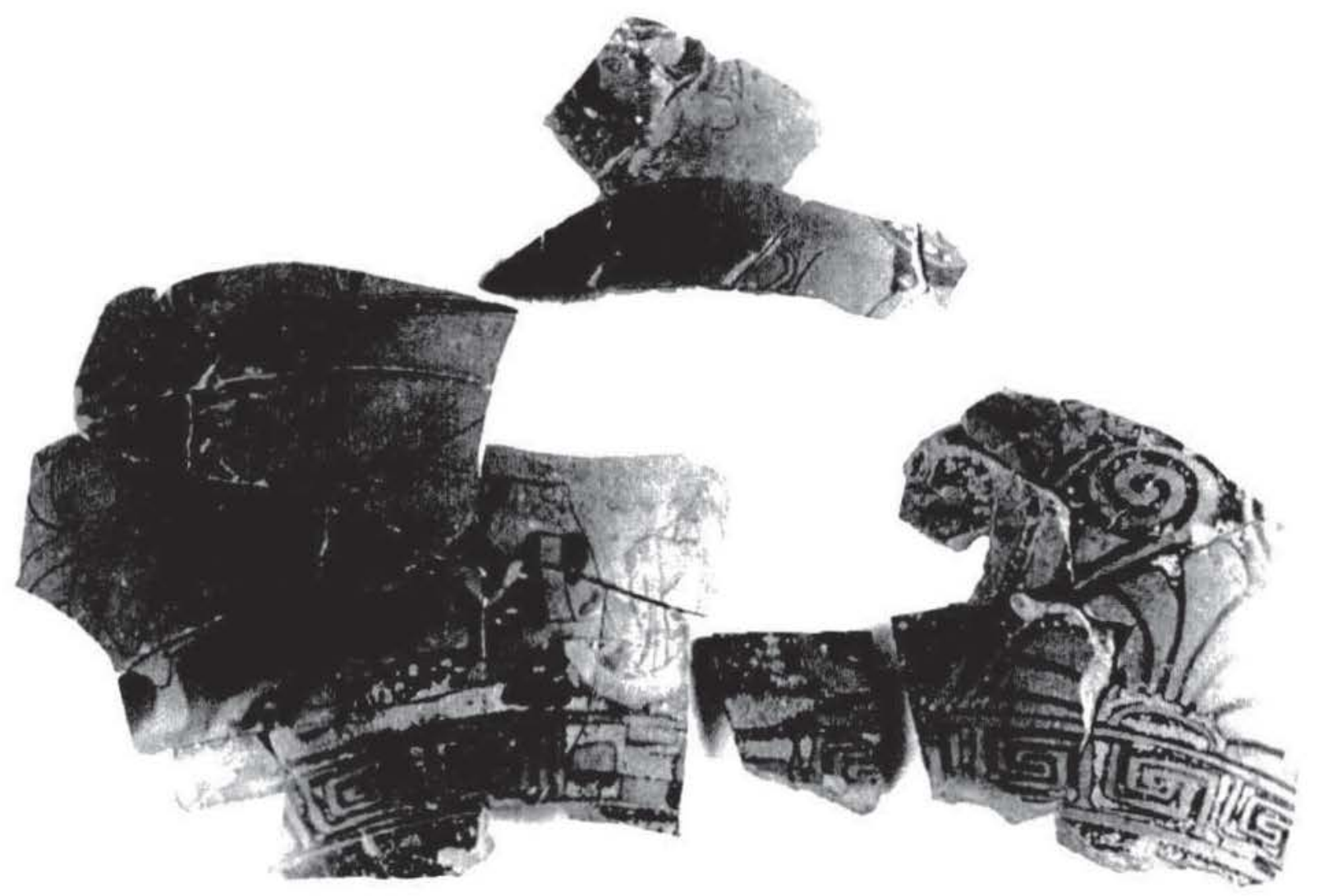

Fïgura 16.-Crátera núm. 6. Cuádriga conduciendo a Hércules al Olimpo. (Foto J. L. Montero).

lao (Metzger, H., 1951, 211-212) o se recogía el momento de la apoteosis con Hércules en presencia de los restantes dioses del Olimpo (como la crátera del Cabecico del Tesoro, véase García Cano, J. M., 1982, 62-63, núm. 20, lámina 2-1 a 3, con la bibliografía precedente) o en compañía de su divina esposa Hebe (Boardman, J., 1989, núm. 400).

\subsection{Escena marina}

Número 5. Crátera ática de campana de figuras rojas. Fragmentada e incompleta. Se conservan 45 fragmentos. Le falta el borde, las asas y parte del pie. $\mathrm{DM}=145 \mathrm{~mm}$. por $166 \mathrm{~mm}$. Segundo cuarto del siglo IV a. C.

Barniz negro brillante, suave; trasluce los surcos del torno. En el fondo interno, disco de color rojizo, debido al apilamiento en la cocción. Pasta color naranja claro, homogénea, bien depurada.

Exterior: en la boca hojas de laurel hacia la izquierda; ovas entorno al arranque de las asas. En la unión del cuerpo con la boca una línea sin barnizar. Pie con dos molduras, debajo de las 
cuales se encuentran dos franjas reservadas. La unión del cuenco del vaso con el pie con una lineat en reserva al igual que el fondo externo y la superficie de reposo.

Debajo de la escena figurada, franja de grecas y ajedre/ados. Bajo las asas palmetas de las que unicamente se conservan restos de tres pétalos.

a) Escena con tema marino (figura 17). Se conservan dos grandes fragmentos, uno de la parte superior y otro de la base.

Arriba se observa una cabeza masculina de perfil, mirando hacia la i/quierda. Sujeta un tridente con su mano, la cual no se conserva. El tridente está realizado en pintura blanca sobrepintada. Es el dios Posidón con su atributo, tocado con una corona de hojas y adornos en blanco superpuesto. Por detrás del dios se observa un brazo, probablemente el derecho, de un personaje femenino, con la mano sobre la cabeza de Posidón. Ambos observan un monstruo marino que se dirige hacia ellos.

El fragmento inferior corresponde también al inicio de la escena por la derecha. En el centro las piernas cruzadas de Posidón con los pies sobre las olas. Detrás de él se observan los últimos pliegues del peplos y manto de la mujer, con los pies en pintura blanca. El derecho sobre una roca, el otro adelantado sobre una ola. Ambos dirigidos hacia la izquierda.

Ante ellos la parte inferior del monstruo marino. Las escamas están formadas por seis filas de puntos. En la parte delantera lleva dos aletas que se apoyan en cuatro olas realizadas con pintura blanca superpuesta, colocadas encima de la base decorativa de la escena. Entre la panza del monstruo y las piernas de Posidón se conserva la parte inferior de unas alas, seguramente de Eros.

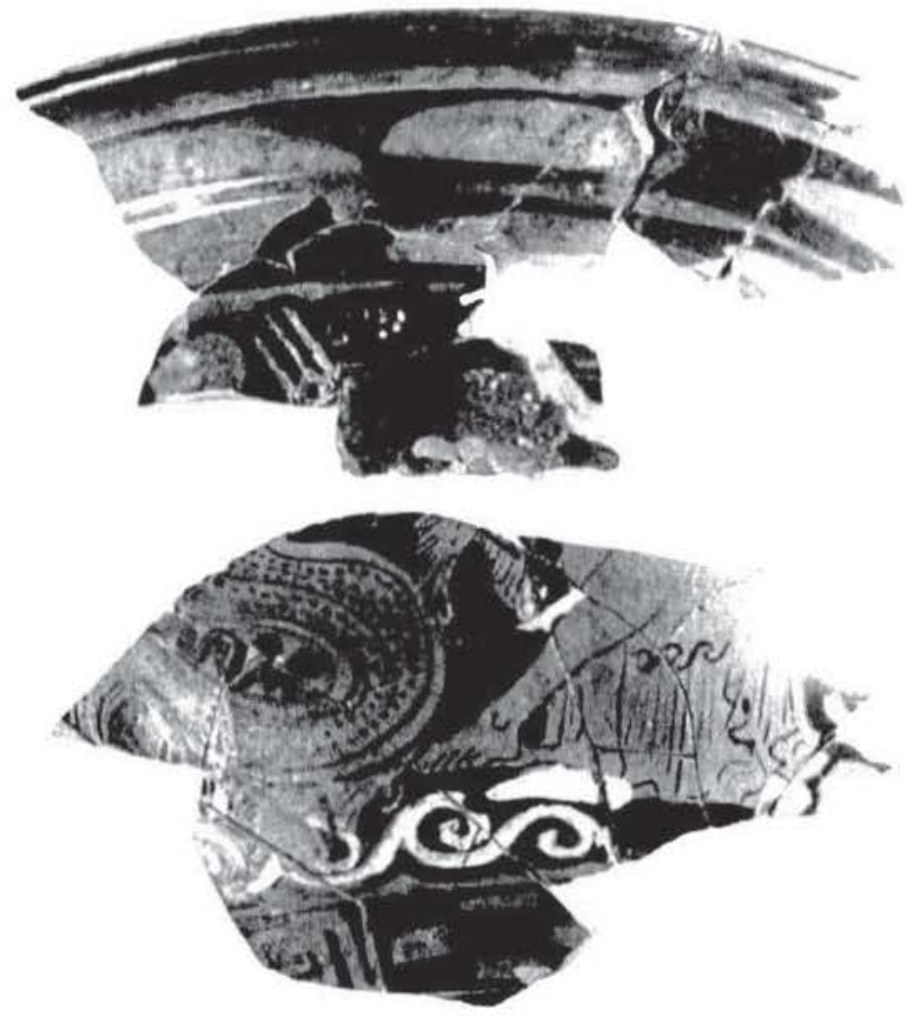

Figura 17.-Crátera núm. 5. Escena de tema marino. (Foto J. L. Montero). 
b) Apenas se conserva. En un fragmento se observa parte de un efebo joven que quizás sostiene un estrígilo; delante un $i$ aríbalo? cuelga del techo. Este joven cerraría la escena por la derecha, donde aparecen restos de la palmeta de debajo del asa. Los detalles anatómicos están confeccionados de manera muy sumaria.

Nos encontramos ante un tema marino, que se desarrolla entre el mar y la costa. Aunque falta una parte del vaso y por lo tanto de la concepción completa del motivo iconográfico representado. No obstante podemos vislumbrar el argumento elegido. La parte de la crátera conservada en dos fragmentos nos muestra el desarrollo de la escena de izquierda a derecha. En primer lugar está situado el monstruo marino, bien dibujado con escamas y aletas, éste se enfrenta a dos personajes, uno es el dios Posidón con tridente y corona de frutos que lo mira y que apoya sus pies en una ola, junto a él hay una mujer con peplo que le cae hasta los pies con las carnaciones en blanco. Finalmente se ha preservado la parte inferior de unas alas ${ }_{i}$ Eros? colocadas entre el monstruo y Posidón.

Analizados los fragmentos que restan de esta crátera se puede inferir que el tema iconográfico representado es una escena con Posidón en la que está presente el amor, por tanto pensamos que la acompañante del dios es la nereida Anfitrite que se convirtió en su mujer legítima. El monstruo desgraciadamente incompleto podría ser una representación de Nereo, padre de Anfitrite que tenía capacidad de metamorfosearse en cualquier tipo de animal o monstruo marino. El instante ofrecido por la crátera sería el momento en que Anfitrite tras una primera negativa para acceder al matrimonio con el dios que le lleva a esconderse con Oceano primero y con Atlante después, cede a la propuesta de Posidón, tras haber sido encontrada por un delfín a quien posteriormente Posidón en agradecimiento convertiría en una constelación.

También es frecuente representar a este matrimonio en su carro tirado por monstruos marinos, razón por la cual el monstruo de nuestro vaso podría ser uno de los que suelen representarse cerca de las divinidades del mar formando parte de su cortejo.

No obstante al quedar incompleta la escena, se puede hipotetizar con lo que podría completar la composición en la que como mínimo, en función del espacio que falta y del tamaño del vaso, cabrían todavía dos personajes hacia la izquierda. Si tenemos en cuenta las preferencias temáticas y el gusto existente en el siglo IV a. C., por ciertos temas en los que se representan monstruos marinos, nos viene a colación rápidamente la historia de Andrómeda en cualquiera de las versiones de Eurípides y Sófocles (Metzger, H., 1951, 340-342). En este caso la parte perdida nos mostraría a Andrómeda atada a unos árboles o a una roca junto al mar para ser devorada por un monstruo marino $k$ êtos (para la representación de monstruos marinos en el mundo clásico, véase Boardman, 1987, 73-84), enviado por Posidón para castigar la soberbia de su madre Casiope quién se había jactado de ser más bella que las nereidas. La única salvación del reino sería exponer a su hija al monstruo.

En este caso Posidón y Anfitrite estarían en el mar observando al monstruo que emerge para devorar a Andrómeda, la presencia de Eros en esta reconstrucción habría que interpretarla como nexo de unión de los dioses del mar o bien como símbolo del amor que inmediatamente va a surgir entre Perseo y Andrómeda. Perseo se situaría en el extremo del vaso detrás de Andrómeda. Sería su salvador quedando tan perdidamente enamorado de la heroina que inmediatamente después de su salvación contraería matrimonio con ella. 


\section{3. ¿Purificación de Orestes?}

Número 4. Crátera ática de campana de figuras rojas. Fragmentada, muy incompleta. Conserva 12 fragmentos. $D M=220 \mathrm{~mm}$. por $108 \mathrm{~mm}$. Segundo cuarto del siglo IV a. C.

Bamiz negro brillante, con tonos rojizos en el interior, deja traslucir los surcos del torno. Bien adherido, un poco picado el interior. Pasta anaranjada, blanda, un poco exfoliada, bien depurada y fina.

Exterior, en el borde hojas de laurel hacia la izquierda; sobre ellas una línea en reserva en el borde, y otra en la unión entre el borde y el cuerpo. El arranque de las asas está delimitado por un friso de ovas. El espacio de debajo de las asas está decorado con dos palmetas superpuestas de nueve pétalos rodeado por dos roleos a cada lado y un caulículo. Sólo se conserva un poco de la parte superior de la escena.

a) En la izquierda se observa la parte superior de un animal, con un asta dirigida hacia la derecha, probablemente un toro. Delante de éste se observa la frente y el pelo de un personaje masculino, con corona de laurel y puntos blancos. Ante él una guirnalda en pintura blanca colgada desde la parte superior. En el centro de la escena aparece un brazo de hombre, que agarra una rama de laurel con puntos blancos entre las hojas. Cierra la escena por el lado derecho un personaje masculino tocado con pétasos en pintura blanca, vestido con la clámide y portando dos lanzas (figura 18).

De esta crátera apenas conservamos el borde y por lo tanto únicamente la parte superior de la escena representada. Los elementos de que disponemos son la parte anterior de la cabeza de un posible bucranio, cuyo cuerno izquierdo está adornado con una guirnalda en blanco. Delante se distingue una pequeña porción de la cabeza de un personaje probablemente masculino con una corona de hojas con frutos en blanco hacia su izquierda. Delante de él una gran guirnalda o cinta en blanco que parece diferenciar este ambiente, quizás sagrado,del resto de la composición. Los dos personajes representados en el centro de la imagen no se conservan excepción hecha de un gran arbusto de laurel con frutos en el que se apoya uno de ellos. En el extremo izquierdo del vaso otra figura masculina con pétasos y dos lanzas en su hombro izquierdo, parece que observa lo que sucede. Tendríamos un último detalle, un pequeño rizo o cuerno que se aprecia en el centro de la composición entre el arbusto y el recinto sagrado.

Establecer una reconstrucción satisfactoria de la imagen con los fragmentos que se han preservado es arriesgado, sin embargo y a modo de hipótesis se pueden plantear varios temas:

Se podría pensar en un sacrificio en donde el rizo o cuerno fuera de un carnero llevado al altar, que estaría situado delante del arbusto de laurel, composición parecida a la de una crátera de campana del pintor de Chrysis procedente de Capua (Boardman, J., 1989, núm. 183).

La segunda hipótesis de trabajo sería la vinculación de la escena con la purificación de Orestes en Delfos después de haber cometido el asesinato de Clitemnestra y Egisto, para vengar la muerte de su padre Agamenón. En este caso el personaje que se apoya en el arbusto de laurel sería el dios Apolo, mientras que el personaje recluido en el recinto sagrado con el bucranio sería Orestes. Delante de ellos se colocaría el altar de sacrificio y el joven que contempla el desarrollo de la escena sería Pilades, el inseparable amigo de Orestes (Overbeck, J., 1857, 714717 , núm. 55 y 58 , lámina XXIX 7 y 12).

Una tercera opción podría ser el sacrificio de Ifigenia a manos del adivino Calcante, para lograr que pasase la calma que impedía a la flota aquea partir hacia Troya. En este caso la re- 

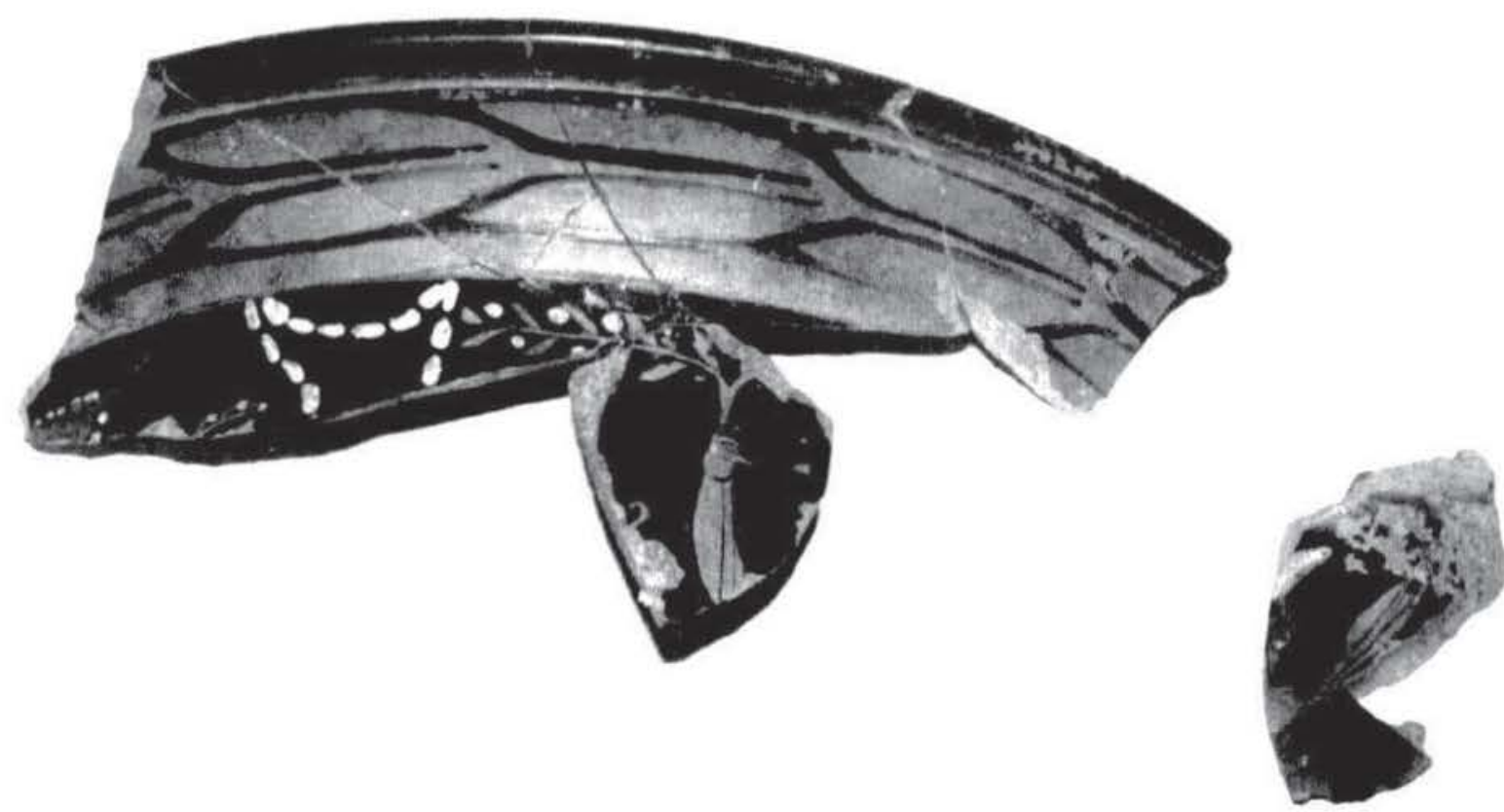

Figura 18.-Crátera núm. 4. ¿Purificación de Orestes en Delfos? (Foto Museo de Murcia).

construcción es más complicada todavía. El personaje del arbusto podría seguir siendo Apolo, delante del cual se situaría Calcante y el altar; el rizo o cuerno pertenecería al animal que en el último intante sustituiría en el sacrificio a Ifigenia, normalmente una cierva. En este caso el personaje de la derecha podría ser Agamenón, pero lo reducido del tamaño del vaso no permitiría la introducción de más figuras consustanciales a este drama como la diosa Artemis, causante de la calma por una ofensa realizada por Agamenón, o la propia Ifigenia (Overbeck, J., 1857. 317. 318, múm. 2, lámina XIV-9).

Una última solución podría ser la llegada de Orestes y Pilades a la Táuride, donde Ifigenia habría sido transportada por Artemis en el instante del sacrificio, y donde era sacerdotisa, tal y como recoge Eurípides (Ifigenia en Táuride, 1541 y ss.). En este caso Orestes y Pilades serían los dos personajes situados a la derecha, uno agarrado al árbol y el otro a su izquierda con las dos lanzas. En el otro lado de la escena estaría el recinto sagrado simbolizado por el bucranio y las cintas en blanco. Faltaría el altar e Ifigenia además de la imagen de Artemis que Orestes vendría a robar para acabar de purificarse por haber asesinado a Clitemnestra, siguiendo nuevamente la versión de Eurípides (Orestes).

No obstante se plantea el mismo problema que en el caso precedente, la falta física de espacio para insertar todos los personajes precisos (Boardman, J., 1989, núm. 350).

Después de haber expuesto varias hipótesis sobre el tema representado en el anverso de esta crátera, pensamos que la más plausible dentro de la imprecisión en la que nos movemos y teniendo en cuenta el espacio expositivo y los personajes necesarios para representar el mito se- 
ría la purificación de Orestes (para este tema véase Overbeck, J., 1857, 710-719), episodio del ciclo troyano al que se recurre en mayor o menor medida en la cerámica ática del siglo IV a. C. (Metzger, H., 1951, 295-297).

\section{CONSIDERACIONES FINALES}

Nos encontramos ante un hallazgo de singular importancia ya que se ha producido en un yacimiento indígena del que si bien se conocían materiales áticos de figuras rojas de cierto valor como la kylix de rojo coral y otros fragmentos con cronología del siglo $\mathrm{V}$ a. C., hay que señalar que no pasaban de ser fragmentos de vasos muy atomizados (García Cano, J. M., 1982).

Sin embargo con el hallazgo presente resulta que se documentan en una sola habitación restos de ocho cráteras áticas de campana de figuras rojas, de las que tres están casi completas, $y$ otras tres dan el perfil completo. En segundo lugar hay que destacar el hecho de que todas pertenezcan al mismo período cronológico, y la variedad y riqueza iconográfica de las escenas.

En cuatro cráteras (núm. 2, 3, 7 y 8 ) se representan escenas dionisiacas, cortejo o banquete, tema éste muy frecuente en la cerámica ática de figuras rojas en el siglo IV a. C. (Metzger 1951) y también mayoritario entre las importaciones de cerámica ática que llegan a la península ibérica (una relación de hallazgos de cortejo dionisiaco en la Península Ibérica, véase Villanueva Puig, M. 1986).

Otras dos presentan temas típicos de la cerámica de este período, pero que son escasos en el Occidente mediterráneo. El tema marino con Posidón (crátera núm. 5), y la ascensión de Hércules al Olimpo en una cuádriga (núm. 6). Sin embargo los otros dos motivos aparentemente son de una rareza extraordinaria lo que le confiere una singularidad aún mayor al hallazgo de Los Nietos, y en especial por lo que se refiere a la crátera núm. 1, en donde se contempla la procesión al templo de Apolo Pitio el día siete Pyanopsion, en la que participa el $\pi \alpha \hat{\iota} \varsigma \alpha \dot{\alpha} \varphi t \theta \alpha \lambda \eta \dot{\zeta}$ portando la eiresióne sobre un hombro. Este motivo iconográfico podemos decir que es único en la Península Ibérica hasta la fecha.

En cuanto a la otra crátera con escena poco común en los repertorios del siglo IV a. C., parece esbozarse el tema de la purificación de Orestes.

Por lo que respecta a los pintores que decoran este lote de cráteras podemos señalar la interelación existente entre las de tema dionisiaco y los caracteres generales de ejecución de todo el conjunto, esto es, empleo de pintura sobrepintada en blanco y dorado, unificación temática de los reversos o el tamaño de los vasos. Estos caracteres nos llevan a vincularlas con el Grupo del Pintor de Telos, tal y como lo definió Beazley, con una fuerte conexión entre los pintores integrantes del mismo Telos, Grifomaquia de Oxford, Retorted painter y Tirso Negro (Beazley, J., ARV2, 1406), tan vinculados entre sí que el propio Beazley dudaba en atribuir un vaso al Retorted painter o al pintor del Tirso Negro (Beazley, J., ARV2, 1425-1426).

En función de los detalles compositivos y de los hallazgos peninsulares creemos que al menos las cuatro cráteras con tema dionisiaco pueden adscribirse al círculo del pintor del Tirso $\mathrm{Ne}$ gro. También hay que contemplar la posibilidad de que las cráteras de mejor ejecución, sobre todo el anverso de la núm. 1, aunque muestra evidentes distorsiones anatómicas, es de una calidad superior a las restantes, pudiera haber sido pintada en esta cara por un pintor, y en el re- 
verso por otro, cosa relativamente frecuente en este período como señaló Beazley en varios vasos del pintor de Telos (Beazley, J., ARV2 1427).

El lote de las cráteras áticas estudiadas supone un 21.6 por 100 respecto al total de la cerámica exhumada en la habitación $\mathrm{A}$, mientras que el conjunto de los materiales áticos se sitúa en un 29.7 por 100 (se han documentado también dos platos F. 22 L., una F. 24 L. y un plato F. 21 L.). Esto nos indica que el porcentaje de las cráteras de figuras rojas sobre el total de la cerámica ática constituye más del setenta por ciento.

Este dato es explícito en cuanto a lo inusual del hallazgo. El contexto global en el que aparecieron dentro de la habitación A del poblado, en el que predominaban las ánforas, ibéricas y de importación, y grandes vasos de cerámica ibérica nos induce a pensar que estamos ante un departamento dedicado a almacén.

Las habitaciones circundantes, en proceso de excavación en el momento de redactar estas líneas, contienen ajuares domésticos normales en cualquier poblado ibérico de este período cronológico, lo cual vendría a ratificar la hipótesis expuesta, en la que el departamento A sería un almacén, y las piezas estudiadas destinadas a un comercio redistribuidor. La circunstancia de que en la necrópolis, con cerca de doscientas tumbas excavadas en total, a penas se hayan encontrado escasos fragmentos de cerámica ática de figuras rojas, refuerza esta afirmación. (Cruz Pérez, L., 1987, 183-255; Cruz Pérez, L., 1990; y García Cano, C., 1990).

La Loma del Escorial debió ser un enclave regular para la navegación de cabotaje de agentes comerciales que desde Ampurias recorrían toda la fachada levantina peninsular, convirtiéndose en centro redistribuidor de las importaciones áticas, tanto como escala hacia el Sur por vía marina, como hacia el interior en conexión con los próximos centros de la desembocadura del río Segura.

La localización costera de La Loma del Escorial, y su proximidad a la Sierra Minera de La Unión, le confieren unos caracteres estratégicos que no podían pasar desapercibidos para los pueblos colonizadores al menos desde principios del siglo $\mathrm{v}$ a. $\mathrm{C}$, como lo atestiguan la calidad y la variedad de las importaciones áticas exhumadas hasta la fecha presente.

El mismo origen del poblado y su principal actividad económica durante toda su existencia debió estar en conexión con esta localización próxima a las minas de La Unión, ricas en plata y plomo, como parece indicar la gran cantidad de minerales y escorias de fundición de estos metales que se han atestiguado durante el curso de excavación.

\section{REFERENCIAS BIBLIOGRÁFICAS}

BEAZLEY, J., ARV ${ }^{2}$ : Attic red figure vase painters. Hackers Arts Books, Nueva York, 1984. Reimpresión de la segunda edición.

Boardman, J., 1987: «Very like a whale. Classical sea monters». Monster and Demons in the Ancient and Medieval Worlds. Mainz, 73-84.

BOARDMAN, J., 1988 a: Athenian Black figure vases. Londres.

BOARDMAN, J., 1988 b: Athenian Red figure vases. The Archaic period. Londres.

CRUz PÉREZ, M. L., 1987: «La necrópolis de Los Nietos (Cartagena). Campañas de excavación de 19841985». Memorias de Arqueología 1984. Excavaciones y Prospecciones Arqueológicas en la Región de Murcia 1, Murcia, 183-235.

Cruz Pérez, M. L., 1990: «La necrópolis ibérica de Los Nietos (Cartagena. Murcia)». EAE, núm. 158, Madrid. 
CuAdRADo DiAz., E., 1958: "Otra crátera del pintor del Tyrso Negro». I CEEC, 312-316.

DeubNer. L., 1986: Attische Feste. Hildesheim (Reimpresión de 1932).

Dieil., E., Schubart, H. y P. A. San Martin, 1964: «Los Nietos». Ein Handesplatz des 5 bis 3 Jahrhundertz an der Spanischen Levanteküste. MM 3, 55-83.

DodDS. E. R.. 1986: Los grieges y lo irracional. Madrid.

Garcia Cano, C. 1990): «Notas sobre la necrópolis ibérica de Los Nietos». Verdolay 2. Homenaje a Emeterio Cuadrado. Murcia, 161-171.

Garcia CANO, J. M., 1979-80: «Cerámica áticas de Galera (Granada) en el Museo Arqueológico Provincial de Murcia». Pyrenae 15-16, 229-240.

GarCía CANO. J. M.. 1982: Cerámicas griegas de la Región de Murcia. Biblioteca Básica Murciana núm. 6. Murcia.

Garcia Cano. J. M., Page del. Pozo, V., 1990: «La necrópolis ibérica de Archena. Revisión de los materiales y nuevos hallazgos». Verdolay 2. Homenaje a Emeterio Cuadrado. Murcia, 109-147.

GARCía LóPEZ, J., 1975: La religión griega. Madrid

Jorge ARAgoneses, M., 1969: «El vaso ibérico de Santa Catalina del Monte (Murcia)». AEspA 42, 200204.

Metzger, H., 1951: Les representations dans la ceramique attique du IV eme siecle. París.

NIL.SsON, M. P., 1967: Geschichte der Griechischen Religion I. Munich (Tercera edición).

Olmos. R. GriÑo, B., 1985: «El entorno póntico y la Península Ibérica. Aportaciones iconográficas al problema de la helenización en Iberia y en el mundo Escita». Archaeologia XXXVI, 15-53.

OVERBECK, J., 1857: Die Bildwerke zum Thebischen und Troischen Heldenkreis. Stuttgart, 1857.

PRESEDo Vel.o, J.: «La necrópolis ibérica de Baza». EAE núm. 119. Madrid.

ROSE, H. J., 1959: Religion in Greece and Rome. Nueva York.

SAN MARTín, P. A. 1964: «Primer informe sobre la excavación de La Loma del Escorial. Los Nietos (Cartagena)». NAH VI. Madrid, 157-161.

SIMON, E., 1983: Festival of Attica. An Archaeological commentary. The University of Wisconsine Press.

Tovar, A., 1960: Eurípides. Tragedias. Las Bacantes. Hecuba. Barcelona.

TRÍAS, G. 1967: Cerámicas griegas de la Península Ibérica. Valencia (dos volúmenes).

TRÍAS, G., 1987: «La cerámica ática de figuras rojas» en El barco del Sec (Costa de Calvia. Mallorca). Mallorca, 47-196.

Villanueva Puig, M. C., 1989: «Images de Dionysos et son cortège dans la céramique Grecque du iV siècle en provenence de la Péninsule Ibérique». Grècques et lbères du IV siecle avant Jésus Christ. Commerce et Iconographie. Table ronde tenue à Bordeaux les 16-18 Décembre 1986, París, 297-317.

\footnotetext{
Abreviaturas empleadas:

$\mathrm{Db}$ : Diámetro del borde

h: Altura

hc: Altura conservada

hp: Altura del pie

DM: Dimensiones máximas
} 